University of Warwick institutional repository: http://go.warwick.ac.uk/wrap This paper is made available online in accordance with publisher policies. Please scroll down to view the document itself. Please refer to the repository record for this item and our policy information available from the repository home page for further information.

To see the final version of this paper please visit the publisher's website. Access to the published version may require a subscription.

Author(s): Mark P. Taylor and Lucio Sarno

Article Title: Real Exchange Rate Dynamics in Transition Economies: A Nonlinear Analysis

Year of publication: 2001

Link to published version: http://dx.doi.org/10.2202/1558-3708.1077

Publisher statement: None 


\section{Studies in Nonlinear Dynamics \& Econometrics}

Volume 5, Issue $3 \quad 2001 \quad$ Article 1

\section{Real Exchange Rate Dynamics in Transition Economies: A Nonlinear Analysis}

Mark P. Taylor

University of Warwick
Lucio Sarno

Warwick Business School

http://www.bepress.com/snde

ISSN: $1558-3708$

Studies in Nonlinear Dynamics \& Econometrics is produced by The Berkeley Electronic Press (bepress). All rights reserved. No part of this publication may be reproduced, stored in a retrieval system, or transmitted, in any form or by any means, electronic, mechanical, photocopying, recording, or otherwise, without the prior written permission of the publisher bepress, which has been given certain exclusive rights by the author.

Copyright (C) 2001 by The Berkeley Electronic Press.

This volume was previously published by MIT Press. 


\title{
Real Exchange Rate Dynamics in Transition Economies: A Nonlinear Analysis
}

\author{
Mark P. Taylor \\ Department of Economics \\ University of Warwick \\ mark.taylor@warwick.ac.uk
}

\author{
Lucio Sarno \\ Finance Group \\ Warwick Business School \\ lucio.sarno@warwick.ac.uk
}

\begin{abstract}
We examine the behavior of the real exchange rates of nine transition economies during the 1990s. We propose an empirical model rationalized on the basis of standard economic models in the tradition of Mundell-Fleming-Dornbusch and Harrod-Balassa-Samuelson, allowing explicitly for real interest rate differentials and (implicitly) for productivity differentials to have an impact on real exchange rate equilibrium and employing nonlinear modeling techniques that are consistent with recently developed economic theories and observed regularities. Using a nonlinear multivariate generalization of the Beveridge-Nelson decomposition applied to our models, we also identify the permanent and temporary components of these real exchange rates implied by our estimates. The results have a natural interpretation and clear policy implications.
\end{abstract}

Keywords. real exchange rate, real interest rate, transition economies, nonlinear dynamics

Acknowledgments. The authors are grateful for helpful comments on earlier drafts to Bruce Mizrach (editor), an anonymous referee, David Begg, Laszlo Halpern, and Charles Wyplosz, as well as participants in seminars at Oxford University, the Bank of England, and Southampton University. The authors alone are responsible, however, for any errors that may remain.

\section{Introduction}

The behavior of the real exchange rate in transition economies is one of the most important issues currently facing applied macroeconomists and policymakers. This follows from the importance of the real exchange rate in establishing the degree of competitiveness of an economy and the confidence that the international financial markets place in economies in transition. Surprisingly, however, the relevant academic literature on this issue remains quite sparse and fragmented.

Halpern and Wyplosz (1997) first investigated empirically the behavior of the real exchange rate for a number of transition economies at a relatively early stage of the transition process, providing clear evidence 
that, although some of the real exchange rates examined underwent a short-run depreciation immediately after the abandonment of the command economy, they invariably followed a significant, continuing secular appreciation. Halpern and Wyplosz document and interpret this appreciation and conclude that, whereas for some currencies this phenomenon may be partly due to a reaction against the initial depreciation, in general it appears to be largely caused by real factors as a consequence of the liberalization process. ${ }^{1}$

Grafe and Wyplosz (1999), in addition to confirming the trend appreciation phenomenon, document another stylized fact of real exchange rates in transition economies, namely, that there seems to be no link between real and nominal exchange rate movements, which may justify ignoring nominal aspects in the analysis of the behavior of these real exchange rates. Grafe and Wyplosz then propose a theoretical model that largely explains these facts in terms of the traded-and nontraded-goods sectors following liberalization and the decline of an inefficient and subsidized state sector. Also, although Grafe and Wyplosz abstract from financial markets in their model for purposes of tractability, in discussing the limitations of their model as well as indicating future avenues of research, they conjecture that an important determinant of the real exchange rate in transition economies may be the real interest rate differential, since transition economies have only limited access to international capital markets and real interest rate differentials vis-à-vis industrialized countries may not equalize rapidly.

A further relevant study in this context is Peel and Speight (1996), which provides strong evidence of nonlinear dynamics in the black-market exchange returns for a number of east European black-market exchange rates. They argue that nonlinear dynamics in returns may also induce nonlinearity in the real exchange rate, which would be consistent with a number of recent theoretical papers on real exchange rate determination in the presence of transactions or transport costs as well as with some recent empirical literature on modeling real exchange rate behavior (discussed below).

The relevant literature therefore suggests three key properties of the real exchange rate dynamics of transition economies: a trend appreciation, a large permanent component in real exchange rates (presumably driven by real factors), and possible nonlinear dynamics. In this paper we contribute to the relevant literature in that we examine empirically the behavior of real exchange rates of nine transition economies (Bulgaria, the Czech Republic, Hungary, Latvia, Lithuania, Poland, Romania, the Slovak Republic, and Slovenia) during the 1990s, in an attempt to capture the observed properties described above. In particular, we propose an empirical model that accounts for the trend appreciation observed in the data while also allowing explicitly for real interest rate differentials and (implicitly) for productivity differentials to have an impact on the real exchange rates of these economies, generating permanent deviations from purchasing power parity.

A key feature of our analysis is that, in addition to allowing the real exchange rate equilibrium to shift over time, we also model the adjustment toward that equilibrium in a nonlinear fashion such that the speed of adjustment may be low when the deviation from equilibrium is small but increases more than proportionately with the size of the deviation. The parsimonious nonlinear error correction models we estimate imply plausible economic relationships that perform well empirically and accord with standard economic theory for eight out of the nine transition economies examined.

In addition, employing a nonlinear generalization of the multivariate Beveridge and Nelson (1981) decomposition, we measure the permanent and temporary components in these real exchange rate time series implied by our empirical models, providing evidence that the real exchange rates of these transition economies are driven largely by permanent shocks, consistent with the view that the recent trend appreciation of the real exchange rates of transition economies is mainly due to real rather than nominal factors. In turn, these results have a clear interpretation and important policy implications.

\footnotetext{
${ }^{1}$ Krajnyak and Zettelmeyer (1998) reexamine empirically the competitiveness of transition economies over the sample period 1990-1995, generally providing evidence of the existence of the trend appreciation highlighted by Halpern and Wyplosz for a number of transition countries. See also De Broeck and Slok (2001).
} 
The remainder of the paper is set out as follows. Section 2 briefly sketches the relevant literature on real exchange rate behavior and describes the main complications arising in modeling real exchange rates of economies in transition. Section 3 discusses the data. Section 4 describes our nonlinear econometric modeling strategy, and in Section 5 we report the empirical results from estimating nonlinear dynamic models for the real exchange rate movements of the transition economies examined. In Section 6 we discuss a nonlinear generalization of the multivariate Beveridge-Nelson decomposition, which we employ to decompose the real exchange rates examined using the nonlinear models developed in the previous section. Section 7 concludes.

\section{Real Exchange Rate Determination in Transition Economies}

Theoretical and empirical studies on real exchange rate modeling for mature industrialized, developing, and transition economies may be divided into three broad strands. The first strand is based on the concept of a stable long-run real exchange rate equilibrium level, the second strand assumes a real exchange rate equilibrium that may itself change in response to real shocks, and the third strand is concerned with nonlinearities in real exchange rate movements. The empirical framework we employ below for modeling real exchange rates of transition economies captures the essence of each of these three strands of the literature on real exchange rate determination.

\subsection{Purchasing power parity}

The first strand of the literature essentially considers the purchasing power parity (PPP) hypothesis as the cornerstone of the determination of the real exchange rate equilibrium level. The PPP hypothesis states that national price levels expressed in a common currency should be equal; equivalently, PPP implies that movements in the nominal exchange rate should be proportional to the ratio of national price levels or that the real exchange rate should be constant (e.g., Sarno and Taylor, 2001, and the references therein).

PPP has variously been viewed as a theory of exchange rate determination, as a short- or long-run equilibrium condition, and as an efficient arbitrage condition in either goods or asset markets (Officer, 1982; Dornbusch, 1987; Breuer, 1994; Froot and Rogoff, 1995; Taylor, 1995; Rogoff, 1996; Sarno and Taylor, 2001). Prior to the recent float, the professional consensus appeared to support the existence of a varying but fairly stable real exchange rate over long periods of time among major industrialized countries. The prevailing orthodoxy of the early 1970s, however, assumed the much stronger proposition of continuous PPP. In the mid- to late 1970s, in the light of the very high variability of real exchange rates after the major exchange rates were allowed to float, this extreme position was largely abandoned (see Sarno and Taylor, 2001, and the references therein).

During the 1980s a large amount of work concentrated increasingly on the time series properties of the real exchange rate, $q_{t}$, which can be defined as the deviation from PPP:

$$
q_{t} \equiv s_{t}+p_{t}^{*}-p_{t}
$$

where $s_{t}$ denotes the logarithm of the nominal exchange rate (domestic price of foreign currency) observed at time $t$, and $p_{t}$ and $p_{t}^{*}$ are the logarithms of the domestic and foreign price levels, respectively. Although $q_{t}$ may be subject to considerable short-run variation, a necessary condition for PPP to hold in the long run is that the real exchange rate $q_{t}$ be stationary over time, not driven by permanent shocks. If this is not the case, then the nominal exchange rate and the price differential will permanently tend to deviate from one another. In fact, a number of studies published mostly in the 1980s could not reject the hypothesis of random-walk behavior in the major real exchange rates (e.g., Adler and Lehmann, 1983), and related work failed to find cointegration between nominal exchange rates and relative prices (e.g., Enders, 1988; Taylor, 1988; Mark, 1990), further reducing professional confidence in PPP and leading to the widespread belief that PPP was of little or no use empirically (e.g., Dornbusch, 1987). 
In general, however, although a number of researchers using single-equation tests for nonstationarity of real exchange rates among developed industrialized countries during the recent float have been unable to reject the null hypothesis of unit root behavior, ${ }^{2}$ some evidence of mean reversion in real exchange rates has been provided by the empirical literature either using long sample periods (e.g., Edison, 1987; Kim, 1990; Lothian and Taylor, 1996), or employing multivariate unit root tests (e.g., Abuaf and Jorion, 1990; Frankel and Rose, 1996; Wu, 1996; Chinn and Johnston, 1997; Papell, 1998; Sarno and Taylor, 1998; Taylor and Sarno, 1998), or using segmented trends (Hegwood and Papell, 1998; Papell, 1999), or else employing nonlinearly mean-reverting models (e.g., Michael, Nobay, and Peel, 1997; Sarno, 2000; Taylor, Peel, and Sarno, 2001). Nevertheless, as mentioned above, the relevant literature to date has concentrated largely on real exchange rates prevailing among mature capitalist industrialized economies in which similar rates of growth may be assumed and-less often—on developing economies, whereas very little evidence exists on transition economies' real exchange rate behavior.

\subsection{A stochastic trend in real exchange rates}

In the analysis of less developed economies and economies in transition, there are good economic reasons why real exchange rates should contain permanent components, particularly where the price indices used in the construction of the real rate contain both tradables and nontradables in prices. In particular, the Harrod-Balassa-Samuelson (HBS) effect (Harrod, 1933; Balassa, 1964; Samuelson, 1964) implies that relatively fast-growing countries may have a tendency to have higher and appreciating real exchange rates based on relative consumer price indices. Nevertheless, the empirical relevance of the HBS effect for the long-horizon time-series behavior of real exchange rates among industrialized countries remains a matter of debate, possibly because of the effects of technology diffusion; for developing economies as well as for economies in transition, however, there is some evidence supporting the presence of HBS effects (see, e.g., Rogoff, 1996; Bahmani-Oskooee and Rhee, 1996; Halpern and Wyplosz, 1997). ${ }^{3}$ Given the focus of the present paper on the empirical modeling of real exchange rate behavior in transition economies, HBS effects may be expected to play an important role.

In addition, although steps have been taken toward full liberalization in the economies under consideration, capital market integration is still an ongoing process, and hence the real interest rate differential-a major determinant of changes in the real exchange rate according to the traditional Mundell-Fleming-Dornbusch (MFD) model (Mundell, 1961; Fleming, 1962; Dornbusch, 1976)—may generate additional persistence in real exchange rates. One important implication of the MFD model is, in fact, that real bilateral exchange rates and real interest rate differentials should be inversely related and move in opposite directions in the long run (see e.g., Obstfeld and Rogoff, 1996, pp. 622-624, and the references therein). This inverse relationship between the real exchange rate and the real interest rate differential may be formally expressed as

$$
\left[q_{t}-\bar{q}\right]=-\phi\left[r_{t}-r_{t}^{*}\right]+r p_{t}, \quad \phi>0
$$

where $r_{t}$ and $r_{t}^{*}$ denote the domestic and foreign real interest rates respectively; $r p_{t}$ is a stationary process, possibly due to risk premia in the foreign exchange market; and $\bar{q}$ denotes the equilibrium level of the real exchange rate, such as the PPP level (Campbell and Clarida, 1987; Meese and Rogoff, 1988; Edison and Pauls, 1993; Baxter, 1994; Edison and Melick, 1999).

\footnotetext{
${ }^{2}$ An exception is Edison, Gagnon, and Melick (1997), which provides moderate evidence in favor of PPP during the recent floating period for a number of countries. See also Fisher and Park (1991), Cheung and Lai (1993a, 1993b, 1998), and Kouretas (1997).

${ }^{3}$ Besides the issue of traded-goods productivity bias, other arguments may be adduced at a theoretical level to suggest why real exchange rates may have persistent components. For example, differences in aggregate growth rates across countries may induce permanent changes in real exchange rates through preferences if consumers' Engel curves bend toward nontraded goods, although such an effect might not be expected to be particularly strong in transition economies (see e.g., Obstfeld and Rogoff, 1996). See also the argument based on the notion of "cross-country internal relative price structure" recently proposed by Breuer and Lippert (1997).
} 
In practice, the relevant empirical literature, based on data for major industrialized countries, has largely recorded evidence rejecting — or at least failing to support— the relationship described by Equation (2.2). Campbell and Clarida (1987), for example, provide evidence that movements in expected real interest rate differentials have not been sufficiently large and persistent to account for the variability in the real dollar exchange rate. Similarly, Meese and Rogoff (1988) could not establish cointegration between real exchange rates and real interest rate differentials, using various cross-rates among the U.S. dollar, German mark, and Japanese yen. Using cointegration techniques and error correction models, Edison and Pauls (1993) reexamine the real exchange rate-real interest rate differential relationship but conclude that there is little empirical evidence in favor of a systematic relationship and that this result appears to be robust across exchange rates, time periods, and measures of inflation. ${ }^{4}$ Nevertheless, Baxter (1994) criticizes the fact that most econometric tests in the relevant empirical literature have focused mainly on high-frequency or short-term correlations rather than trying to capture the low-frequency or long-term movements in the variables under consideration. Using econometric methods explicitly designed to capture low-frequency movements, Baxter is able to detect some correlation between real exchange rates and real interest rates, attributing the relatively small size of the correlation to the preponderant role of high-frequency exchange rate movements in explaining the total variation in real exchange rate movements.

None of the studies cited above has, however, focused on transition economies. One important feature of transition economies' real exchange rates, discussed above, is that after the abrupt depreciation accompanying the end of the command economy and in some cases the dismantling of previously prevailing multiple exchange rates, a strong trend appreciation typically ensued for a number of reasons. In particular, the appreciation may be rationalized not only as a correction to the initial depreciation, but also because of the rapid productivity gains occurring when formerly inefficient command economies began to respond to market forces, thereby generating HBS effects, since these productivity gains may be expected to be larger in the traded than in the nontraded sector (Halpern and Wyplosz, 1997; Grafe and Wyplosz, 1999; Krajnyak and Zettelmeyer, 1998). As suggested by Grafe and Wyplosz (1999), moreover, in addition to HBS effects, the continuous real appreciation may also partly reflect real wage appreciation that ensues as labor is bid away from the state sector, which is then forced to close down inefficient production lines.

Overall, therefore, an empirical framework suitable for modeling the real exchange rate of a transition economy has to capture its appreciating trend while allowing for a permanent, non-mean-reverting component driven by the permanent movements in real interest rate differentials or by HBS or labor effects or other factors highlighted by the literature in this context. In addition to a permanent component governing the stochastic equilibrium trend of the real exchange rates of transition economies, one may still expect deviations from that equilibrium to dissipate because of forces such as the effects of international goods arbitrage. Clearly, the transitory component in the real exchange rate may be driven by nominal (monetary or financial) shocks generating moderately persistent but ultimately mean-reverting deviations of the real exchange rate from its equilibrium.

\subsection{Nonlinearities in real exchange rate dynamics}

An intuitively appealing emerging theoretical literature on the nature of international goods arbitrage suggests that real exchange rate adjustment may arise in an inherently nonlinear fashion. At the simplest level, one can imagine arbitrage in a single, homogeneous traded good becoming strong only once arbitrage yields sufficient profit to outweigh transport and other costs of arbitrage, so that deviations from the law of one price (LOOP) might be expected to switch abruptly from non-mean-reverting (when the deviation from the LOOP is smaller

\footnotetext{
${ }^{4}$ See also Edison and Melick (1999).
} 
than the arbitrage costs) to mean-reverting (once the deviation is greater than the arbitrage costs). This would suggest that one might find evidence of threshold nonlinearity - that is, a discrete switch from non-mean reversion to mean reversion at a certain distance from the equilibrium level (Tong, 1990)—when examining deviations from the LOOP using disaggregated data (Obstfeld and Taylor, 1998). A number of authors, however, have put forward more sophisticated models of goods arbitrage in the presence of transactions costs and have shown that deviations from the LOOP may behave in a more complicated nonlinear manner in such circumstances (see, e.g., Benninga and Protopapadakis, 1988; Dumas, 1992; Sercu, Uppal, and Van Hulle, 1995). Moreover, given that deviations from PPP calculated using aggregate national price indices may largely represent an aggregation of deviations from the LOOP for a wide range of goods each of which may have a different level of transactions costs, a smooth rather than an abrupt rise in the degree of mean reversion might be expected as the size of aggregate deviations from PPP increases and the number of goods being arbitraged rises (e.g., Taylor, Peel, and Sarno, 2001). ${ }^{5}$

The above discussion suggests the importance of allowing for nonlinearity in modeling the adjustment of real exchange rates toward their long-run equilibrium. At the empirical level, Michael, Nobay, and Peel (1997) use the Lothian and Taylor (1996) long span of annual data on dollar-sterling and franc-sterling exchange rates as well as monthly data for three real exchange rates during the interwar period and show that statistically significant nonlinearity characterizes the adjustment toward equilibrium of the real exchange rate series examined, successfully modeled as exponential smooth-transition autoregressive processes (Granger and Teräsvirta, 1993). Similar findings are recorded by Taylor, Peel, and Sarno (2001) using data at various frequencies and for a number of major real exchange rates during the recent float alone. Also, Peel and Speight (1996) find strong evidence of nonlinear dynamics in the black-market exchange returns for a number of east European black-market exchange rates and argue that nonlinear dynamics is likely to be present also in the corresponding real exchange rates. Hence, mean reversion of the real exchange rates of transition economies toward their possibly shifting equilibrium levels may be expected to occur nonlinearly.

\section{Data}

Monthly data on nominal end-of-period exchange rates against the German mark as well as producer price indices $^{6}$ and long-term interest rates ${ }^{7}$ were obtained from the International Monetary Fund's International Financial Statistics and the Organisation for Economic Cooperation and Development's Main Economic Indicators. From these data we constructed the real bilateral mark exchange rate $(q)$ in logarithms according to the identity (2.1), with $p^{*}$ taken as the German producer price deflator. We also constructed real interest rates and real interest rate differentials, $r-r^{*}$, where $r^{*}$ denotes the German real long-term government bond interest rate. The real exchange rate data were put into logarithmic mean-deviation form prior to the analysis. Whereas the end date of the sample period is identical across countries, the start date differs because of differences in data availability. Precisely, the sample period is 1994M1-1997M12 for Bulgaria; 1993M1-1997M12 for the Czech Republic, Slovak Republic, and Lithuania; 1989M1-1997M12 for Hungary; 1992M7-1997M12 for Latvia; 1990M1-1997M12 for Poland; 1992M8-1997M12 for Romania; and 1992M1-1997M12 for Slovenia.

\footnotetext{
${ }^{5}$ Nevertheless, some studies have used threshold-type models also in the context of PPP. Notably, see Enders and Falk (1998).

${ }^{6}$ For countries for which the producer price index was not available, we used the consumer price index.

${ }^{7}$ In several transition economies, where liberalization of financial markets is a very recent phenomenon and is still in progress, long-term bonds do not exist. In those cases, we used the best available proxy.
} 


\section{Nonlinear Econometric Modeling Strategy}

\subsection{The long-run model, cointegration, and nonlinearity}

If we allow for trend appreciation of the equilibrium real exchange rate due to HBS and the other effects discussed above, and if, in addition, each of the real exchange rates and the real interest rate differentials is an integrated stochastic process of order one or $I(1)$, then the MFD framework encapsulated in Equation (2.2) suggests that a logical econometric strategy in the present context would be to test for cointegration in a regression of the type:

$$
q_{t}=\alpha+\beta t+\gamma\left(r-r^{*}\right)_{t}+z_{t}
$$

where $t$ is a time trend, and $z_{t}$ is an error term. ${ }^{8}$

Although the literature investigating the relationship between real exchange rates and real interest rate differentials typically tests for linear cointegration and employs conventional unit root tests on the retrieved estimated residuals from an equation such as (4.1), the theoretical and empirical literature on real exchange rate determination in the presence of transactions costs discussed in Section 2 provides a strong rationale for nonlinear mean reversion in the cointegrating residuals such that adjustment toward equilibrium is faster the greater the deviation from equilibrium. In this context, however, conventional linear cointegration tests may have low power against nonlinear mean-reverting alternatives and therefore may not necessarily be able to detect stationarity of the residuals from (4.1) (Balke and Fomby, 1997).

The alternative strategy, pursued in this paper, is to test for linearity of the residuals from (4.1) and, if linearity is rejected against the alternative of a nonlinearly mean-reverting model, to fit a stationary nonlinear autoregressive model to the residuals. Rejection of the linearity hypothesis together with the ability to fit a plausible stationary nonlinear model to the residuals from (4.1) would then lead us to establish nonlinear cointegration.

The characterization of the nonlinear adjustment process we first consider in the empirical analysis is in terms of a smooth transition autoregressive (STAR) model (Granger and Teräsvirta, 1993; Teräsvirta, 1994, 1998) in which adjustment takes place in every period but the speed of adjustment varies with the extent of the deviation from equilibrium. Essentially, STAR models allow the dynamics of a time series process to move smoothly between two extreme regimes in which the mean-reverting properties of the process may be quite different. In the inner regime, for example, when the process is in the neighborhood of its long-run equilibrium, its behavior may in fact be that of a unit root process, whereas in the extreme outer regime, for very large deviations from equilibrium, the process may be strongly mean-reverting. For intermediate deviations from equilibrium, the behavior will be governed by a mixture of these two regimes. Nevertheless, inadequacy of STAR models to describe the behavior of the equilibrium error from model (4.1) may be expected to show up in the nonrejection of the linearity test statistics employed here (as these are tests of the null hypothesis of linearity against the specific alternative hypothesis of STAR-type nonlinearity) or in the inability to fit a STAR model with plausible estimates of the parameters.

Hence, let us assume that the error term in (4.1) can be described by the logistic STAR (LSTAR) model or by the exponential STAR (ESTAR) model given by equations (4.2) and (4.3), respectively:

$$
\begin{aligned}
& z_{t}=\pi_{10}+\boldsymbol{\pi}_{1}^{\prime} \mathbf{w}_{t}+\left(\pi_{20}+\boldsymbol{\pi}_{2}^{\prime} \mathbf{w}_{t}\right)\left[1+\exp \left\{-\lambda_{L}\left(z_{t-d}-c_{L}\right)\right\}\right]^{-1}+u_{1 t} \\
& z_{t}=\mu_{10}+\boldsymbol{\mu}_{1}^{\prime} \mathbf{w}_{t}+\left(\mu_{20}+\boldsymbol{\mu}_{2}^{\prime} \mathbf{w}_{t}\right)\left[1-\exp \left\{-\lambda_{E}\left(z_{t-d}-c_{E}\right)^{2}\right\}\right]+u_{2 t}
\end{aligned}
$$

\footnotetext{
${ }^{8}$ The assumption of an $I(1)$ real interest rate differential series is a standard assumption in the literature testing for the existence of a real exchange rate-real interest rate differential relationship, even among industrialized countries (see, e.g., Meese and Rogoff, 1988, or the other studies cited above in this context). In fact, this assumption seems to be more warranted for the real interest rate differentials holding between transition and developed economies, presumably due to less than full integration of transition economies' capital markets and global markets.
} 
where $\pi_{10}, \mu_{10}, \pi_{20}, \mu_{20}, c_{L}$, and $c_{E}$ are constants; $\boldsymbol{\pi}_{j}=\left(\pi_{j 1}, \ldots, \pi_{j p}\right)^{\prime}$ and $\boldsymbol{\mu}_{j}=\left(\mu_{j 1}, \ldots, \mu_{j p}\right)^{\prime}$ for $j=1,2$; $\mathbf{w}_{t}=\left(z_{t-1}, \ldots, z_{t-p}\right)^{\prime}$; the integer $d>0$ is a delay parameter; $u_{1 t} \sim$ i.i.d. $\left(0, \sigma_{u_{1}}^{2}\right)$ and $u_{2 t} \sim$ i.i.d. $\left(0, \sigma_{u_{2}}^{2}\right)$; and $\lambda_{L}, \lambda_{E}>0$. The expressions $F_{L}\left(z_{t-d}\right)=\left[1+\exp \left\{-\lambda_{L}\left(z_{t-d}-c_{L}\right)\right\}\right]^{-1}$ and $F_{E}\left(z_{t-d}\right)=\left[1-\exp \left\{-\lambda_{E}\left(z_{t-d}-c_{E}\right)^{2}\right\}\right]$ in (4.2) and (4.3), respectively, denote the transition functions that characterize the transition of $z_{t}$ from one regime to another, and the parameters $\lambda_{L}$ and $\lambda_{E}$ determine the speed of the transition between the two regimes for the LSTAR model and the ESTAR model, respectively. The transition function of the LSTAR is a monotonically increasing function of $z_{t-d}$ and yields asymmetric adjustment toward $c_{L}$, whereas the transition function of the ESTAR is symmetric about $c_{E}$, although the tendency to move back to equilibrium is stronger the larger the deviation from equilibrium.

In our empirical analysis, we select the most adequate STAR formulation to model the error term from (4.1) on pure econometric grounds, following a selection procedure due to Teräsvirta (1994), although the theoretical models of real exchange rate determination in the presence of transactions costs discussed in Section 2 clearly seem to be consistent with the type of nonlinear behavior captured by an ESTAR model, since this implies symmetric adjustment of the real exchange rate above and below equilibrium (see Michael, Nobay, and Peel, 1997; Taylor, Peel, and Sarno, 2001). ${ }^{9}$

Also, it should be clear that the potential presence of nonlinearities has important implications for standard linear unit root tests applied to the residuals from a static regression as a test for cointegration. To see this, consider the following reparameterization of the ESTAR model (4.3):

$$
\begin{aligned}
\Delta z_{t}= & \mu_{10}+b z_{t-1}+\sum_{i=1}^{p-1} b_{i} \Delta z_{t-i}+\left(\mu_{20}+b^{\prime} z_{t-1}+\sum_{i=1}^{p-1} b_{i}^{\prime} \Delta z_{t-i}\right) \\
& \times\left[1-\exp \left\{-\lambda_{E}\left(z_{t-d}-c_{E}\right)^{2}\right\}\right]+u_{2 t}
\end{aligned}
$$

where $\Delta$ denotes the first-difference operator. So long as $\left(b+b^{\prime}\right)<0$, this STAR formulation will display global stability, given the limiting behavior of the transition function. This condition does not, however, rule out the possibility that $b=0$, implying unit root behavior in the neighborhood of equilibrium, or even that $b>0$. A standard linear Dickey-Fuller test applied to the data will implicitly be based on a linear combination of $b$ and $\left(b+b^{\prime}\right)$, the weights of which will depend upon the distribution of $z_{t}$ over the sample period. Thus, we may be unable to reject the null hypothesis of cointegration between $q_{t}$ and $\left(r-r^{*}\right)_{t}$ (i.e., of a unit root in $z_{t}$ ) in Equation (4.1) even though $z_{t}$ is nonlinearly mean-reverting and therefore $q_{t}$ and $\left(r-r^{*}\right)_{t}$ are cointegrated (see Balke and Fomby, 1997; Michael, Nobay, and Peel, 1997; Taylor, Peel, and Sarno, 2001).

\subsection{Linearity testing and nonlinear dynamic modeling}

When $\lambda_{L}=0$ or $\lambda_{E}=0$, the linearity hypothesis may be expressed as $H_{0}: \lambda_{L}=0$ or $H_{0}: \lambda_{E}=0$, respectively. Equations (4.2) and (4.3), however, are only identified under the alternative hypotheses $H_{1}: \lambda_{L}>0$ or $H_{1}: \lambda_{E}>0$. This problem may be overcome by taking a low-order Taylor series approximation of the transition function and then reparameterizing (see Luukkonen, Saikkonen, and Teräsvirta, 1988). Teräsvirta (1994) derives Lagrange multiplier (LM)-type tests of linearity against LSTAR or ESTAR models and also suggests a decision rule for choosing between LSTAR and ESTAR formulations. If the delay parameter $d$ is fixed, the linearity test against STAR consists of estimating the auxiliary regression

$$
\begin{aligned}
z_{t}= & k_{00}+\sum_{j=1}^{p}\left(k_{0 j} z_{t-j}+k_{1 j} z_{t-j} z_{t-d}+k_{2 j} z_{t-j} z_{t-d}^{2}+k_{3 j} z_{t-j} z_{t-d}^{3}\right) \\
& + \text { innovations }
\end{aligned}
$$

\footnotetext{
${ }^{9}$ See Granger and Teräsvirta (1993) and Teräsvirta (1994, 1998) for a detailed discussion of the properties of the transition functions of STAR models.
} 
and testing the null hypothesis

$$
H_{0 L}: k_{1 j}=k_{2 j}=k_{3 j}=0
$$

for $j=1, \ldots, p$, against the alternative that $H_{0 L}$ is not valid.

In order to specify $d$, this linearity test is repeated for a set of values $d=1,2, \ldots, D$. If linearity is rejected for more than one value of $d$, then $d$ is determined as the value $(\hat{d})$ that minimizes the $p$-value of the linearity test (i.e., linearity is rejected most strongly when $d=\hat{d}$ ). In practice the $F$-test form of the LM test is used to improve size and power properties, which is particularly important when the order $p$ of the linear AR model is large and the number of observations is small (see Teräsvirta, 1994).

The decision rule proposed by Teräsvirta (1994) for choosing between an LSTAR and an ESTAR model is based on a sequence of nested tests within (4.5). First, the null hypothesis $H_{0 L}$ in (4.6) must be rejected using an ordinary $F$-test $\left(F^{L}\right)$. Then the following hypotheses are tested:

$$
\begin{aligned}
& H_{03}: k_{3 j}=0 \\
& H_{02}: k_{2 j}=0 \mid k_{3 j}=0 \\
& H_{01}: k_{1 j}=0 \mid k_{2 j}=k_{3 j}=0
\end{aligned}
$$

for $j=1, \ldots, p$. Again, an $F$-test is used, with the corresponding test statistics denoted $F^{3}, F^{2}$, and $F^{1}$, respectively, and the decision rule is as follows. ${ }^{10}$ After rejecting (4.6), the three hypotheses (4.7)-(4.9) are tested using $F$-tests. If the test of (4.8) has the smallest $p$-value, an ESTAR model is chosen; otherwise an LSTAR model is selected (see Teräsvirta, 1994, p. 210). Teräsvirta (1994), using Monte Carlo analysis, shows that this method of model selection, which we term the "Teräsvirta rule," performs reasonably well in terms of selecting the correct models and discriminating between ESTAR and LSTAR alternatives.

Hence, our modeling strategy aimed at detecting nonlinear cointegration in (4.1) may be summarized as follows. First, we specify the order $p$ of the linear AR model on the basis of the partial autocorrelation function (PACF) of $z_{t}$ and other standard criteria such as the Akaike information criterion and the Schwartz information criterion. Second, we specify a set of plausible values $(1,2, \ldots, D)$ for $d$. For each value of $d$, we test linearity against STAR using $F^{L}$, the $F$-statistic associated with $H_{0 L}$ in (4.6); if linearity is rejected, we select $d=\hat{d}$ to minimize the marginal significance level of the linearity test. Third, we execute the nested tests (4.7)-(4.9) and use the Teräsvirta rule to choose between LSTAR and ESTAR formulations.

Nevertheless, establishing nonlinear cointegration in Equation (4.1) implies the existence of a nonlinear error correction model, that is to say, the finding of smooth-transition nonlinearity in the residuals from the static cointegrating regression would suggest a smooth-transition regression (STR) for $\Delta q_{t}$, which may be seen as a general "regime-switching" nonlinear error correction model (ECM) where the nonlinearity is determined by values of a transition variable deviating from a fixed value (Granger and Swanson, 1996; Teräsvirta, 1998). In particular, we investigate an ESTAR model in which the transition variable is the lagged cointegrating residuals from (4.1), $z_{t}$, implying the following two-equation system of nonlinear error correction models:

$$
\begin{aligned}
\Delta q_{t}= & \beta+\sum_{i=1}^{p} \zeta_{1 i} \Delta q_{t-i}+\sum_{i=1}^{p} \zeta_{2 i} \Delta\left(r-r^{*}\right)_{t-i}+\rho_{1} \hat{z}_{t-1} \\
& +\left[\beta^{\prime}+\sum_{i=1}^{p} \zeta_{1 i}^{\prime} \Delta q_{t-i}+\sum_{i=1}^{p} \zeta_{2 i}^{\prime} \Delta\left(r-r^{*}\right)_{t-i}+\rho_{2} \hat{z}_{t-1}\right] \\
& \times\left[1-\exp \left\{-\lambda_{1}\left(\hat{z}_{t-d}-\omega_{1}\right)^{2}\right\}\right]+\epsilon_{1 t}
\end{aligned}
$$

\footnotetext{
${ }^{10}$ The sequence of tests is based on the relationship between the parameters of (4.5) and those of the corresponding nonlinear model (see Granger and Teräsvirta, 1993; Teräsvirta, 1994).
} 


$$
\begin{aligned}
\Delta\left(r-r^{*}\right)_{t}= & \kappa+\sum_{i=1}^{p} \xi_{1 i} \Delta q_{t-i}+\sum_{i=1}^{p} \xi_{2 i} \Delta\left(r-r^{*}\right)_{t-i}+\psi_{1} \hat{z}_{t-1} \\
& +\left[\kappa^{\prime}+\sum_{i=1}^{p} \xi_{1 i}^{\prime} \Delta q_{t-i}+\sum_{i=1}^{p} \xi_{2 i}^{\prime} \Delta\left(r-r^{*}\right)_{t-i}+\psi_{2} \hat{z}_{t-1}\right] \\
& \times\left[1-\exp \left\{-\lambda_{2}\left(\hat{z}_{t-d}-\omega_{2}\right)^{2}\right\}\right]+\epsilon_{2 t}
\end{aligned}
$$

where $\epsilon_{1 t}$ and $\epsilon_{2 t}$ are white-noise innovations. The system specification (4.10)-(4.11) is motivated by our preference to model the error corrections simultaneously to take into account any potential endogeneity of $\Delta q_{t}$ and $\Delta\left(r-r^{*}\right)_{t}$.

Assuming a plausible transition variable is $\hat{z}_{t-d}$, the appropriate auxiliary regression for the linearity tests against a STAR alternative is the following:

$$
\hat{v}_{t}=\boldsymbol{\rho}_{0}^{\prime} \mathbf{A}_{t}+\boldsymbol{\rho}_{1}^{\prime} \mathbf{A}_{t} \hat{z}_{t-d}+\boldsymbol{\rho}_{2}^{\prime} \mathbf{A}_{t} \hat{z}_{t-d}^{2}+\boldsymbol{\rho}_{3}^{\prime} \mathbf{A}_{t} \hat{z}_{t-d}^{3}+\text { innovations }
$$

where $\hat{v}_{t}$ is the estimated disturbance retrieved from a general pth-order linear ECM for $\Delta q_{t}$, and $\mathbf{A}_{t}$ denotes the vector of explanatory variables in that ECM (see Teräsvirta, 1998). The general test for linearity against STR, $F^{L^{\prime}}$, is then the ordinary $F$-test of the null hypothesis:

$$
H_{0 L}^{\prime}: \boldsymbol{\rho}_{1}^{\prime}=\boldsymbol{\rho}_{2}^{\prime}=\boldsymbol{\rho}_{3}^{\prime}=\mathbf{0}
$$

for $d \in\{1, \ldots, D\}$, where $\mathbf{0}$ is a null vector. If linearity is rejected for more than one value of $d$, then $d$ is determined as the value $(\hat{d})$ that minimizes the $p$-value of the linearity test, and we set $d=\hat{d}$.

Generalizing the Teräsvirta rule, the choice between a logistic STR (LSTR) and an exponential STR (ESTR) model is based on a sequence of nested tests within (4.12). First, the null hypothesis $H_{0 L}^{\prime}$ in (4.13) must be rejected using an ordinary $F$-test $\left(F^{L^{\prime}}\right)$. Then the following hypotheses are tested:

$$
\begin{aligned}
& H_{03}^{\prime}: \boldsymbol{\rho}_{3}^{\prime}=\mathbf{0} \\
& H_{02}^{\prime}: \boldsymbol{\rho}_{2}^{\prime}=0 \mid \boldsymbol{\rho}_{3}^{\prime}=\mathbf{0} \\
& H_{01}^{\prime}: \boldsymbol{\rho}_{1}^{\prime}=0 \mid \boldsymbol{\rho}_{2}^{\prime}=\boldsymbol{\rho}_{3}^{\prime}=\mathbf{0}
\end{aligned}
$$

Again, an $F$-test is used, with the corresponding test statistics denoted $F^{3 \prime}, F^{2 \prime}$, and $F^{1 \prime}$, respectively, and the decision rule is as follows: after rejecting (4.13) and setting $d=\hat{d}$, the three hypotheses (4.14)-(4.16) are tested using $F$-tests; if the test of (4.15) has the smallest $p$-value, an ESTAR is chosen; otherwise a LSTAR is selected (see Granger and Teräsvirta, 1993; Teräsvirta, 1994, 1998).

\section{Empirical Analysis: Modeling the Real Exchange Rate}

The empirical results from executing augmented Dickey-Fuller test statistics for linear nonstationarity on $q_{t}$ and $\left(r-r^{*}\right)_{t}$ and their first-differences (not reported but available upon request) did not enable us to reject the null hypothesis of unit root behavior for any of the series in levels, but we were able to reject the null of nonstationarity for both series in first differences. ${ }^{11}$ This would suggest that each of $q_{t}$ and $\left(r-r^{*}\right)_{t}$ contains one unit root. It is well known, however, that augmented Dickey-Fuller tests and other conventional tests for unit roots have very low power to reject a false null hypothesis with a short sample span. In fact, for very persistent stationary processes, even a century of data may not be sufficient to reject the null of nonstationarity (see Lothian and Taylor, 1996, 1997). Thus, we do not wish to argue that we model $q_{t}$ and

\footnotetext{
${ }^{11}$ Throughout the paper we use a 5-percent significance level for hypothesis testing, unless explicitly stated otherwise.
} 
$\left(r-r^{*}\right)_{t}$ as first-difference stationary processes in this paper on the basis of our unit root tests results. Rather, we treat $q_{t}$ and $\left(r-r^{*}\right)_{t}$ as first-difference stationary processes, as we think it is plausible to do so in the light of our earlier discussion on the properties of these time series in transition economies during the sample period examined, and because it is consistent with much empirical research in this context (see Meese and Rogoff, 1988; Edison and Pauls, 1993) that argues that very persistent series with a root at least close (if not equal) to unity are better approximated by $I(1)$ processes than by stationary ones (see, for example, Stock, 1997, and the references therein).

Next, we tested for cointegration between the real exchange rate and the real interest rate differential for each of the transition economies considered using a Dickey-Fuller test statistic on the estimated disturbance from equation (4.1) $\hat{z}_{t}$, in accordance with the conventional Engle-Granger two-step procedure (Engle and Granger, 1987), as well as using the Johansen $(1988,1991)$ maximum-likelihood procedure. Using the Engle-Granger procedure, the cointegration tests indicate that the null hypothesis of no cointegration cannot be rejected, with the exception of Bulgaria, Lithuania, and Slovenia. The Johansen maximum-likelihood procedure may, however, be preferred to the Engle-Granger cointegration procedure in this context in the light of the Monte Carlo results provided by Balke and Fomby (1997), who suggest that estimation of the long-run equilibrium using the Johansen cointegration procedure when the true adjustment toward equilibrium is nonlinear performs reasonably well in terms of power and size distortion. Using the Johansen procedure, cointegration could be established, at the 5-percent critical value, for Bulgaria, Hungary, Latvia, Lithuania, Poland, and Slovenia, through both the $\lambda_{\max }$ and the $\lambda_{\text {trace }}$ statistics, although the statistics are very close to the critical value for Hungary. It is known, however, that Johansen tests exhibit finite-sample bias toward rejection of the null hypothesis (see, for example, Cheung and Lai, 1993c; Johansen, 2000, and the references therein). Hence, since reliable response surface results from which to derive finite-sample critical values for the Johansen tests do not exist (to the best of the authors' knowledge), it is reasonable to consider also a more conservative significance level in interpreting our Johansen tests results. If one considers the 1-percent asymptotic critical values (reported in the Note to Table 1), cointegration can still be rejected for five out of nine countries (namely Bulgaria, Latvia, Lithuania, Poland, and Slovenia). Overall, the evidence in favor of stationarity of the cointegrating residuals should, at this stage, be taken with caution.

The maximum-likelihood estimation results reported in Panel B of Table 1 suggest plausible estimates of the cointegrating vector for each of the countries considered. In particular, in each case, the estimated value of $\beta$ is correctly (negatively) signed, consistent with the stylized fact that the real exchange rate in transition economies was appreciating along a trend over the sample. In addition, $\gamma$ is negatively signed, consistent with the prediction of the MFD model as expressed in Equation (2.2). Prima facie, therefore, the empirical results appear to be consistent with the recent literature on the relationship between the real exchange rate and the real interest rate differential, which has provided some support for a systematic relationship between real exchange rates and real interest rates on data for industrialized countries.

Nevertheless, given the prediction of theoretical models of real exchange rate determination and the emerging empirical literature suggesting that significant nonlinearity may characterize real exchange rate dynamics (discussed in Section 2), we examined the validity of the maintained linearity hypothesis underlying conventional unit root and cointegration tests. Thus, we tested for linearity of $\hat{z}_{t}$ for each country considered against the alternative of a STAR model, assuming that the order of the autoregression, $p$, equals unity in accordance with the preliminary inspection of the partial autocorrelation functions of $\hat{z}_{t}$. The results, reported in Table 2, offer strong evidence against linearity and in favor of STAR nonlinearity in the residuals $\hat{z}_{t}$ for each country except for Bulgaria, with $d=1$ for all countries but Latvia, for which the strongest rejection occurs with $d=2$. Also, applying the Teräsvirta rule for deciding between LSTAR and ESTAR in each case in which linearity was rejected indicated clearly that ESTAR nonlinearity characterizes the residuals $\hat{z}_{t}$.

Given that these test statistics explicitly test the null hypothesis of linearity against the alternative of a stationary nonlinear STAR model, rejection of the null hypothesis of linearity may be seen as evidence for 
Table 1

Cointegration analysis

\begin{tabular}{|c|c|c|c|c|}
\hline \multicolumn{5}{|c|}{ Panel A: Cointegration test statistics } \\
\hline & $\begin{array}{l}\text { Engle-Granger } \\
\text { ADF test }\end{array}$ & $\begin{array}{l}\text { Johansen: } \lambda_{\max } \\
g=0 \text { vs. } g=1\end{array}$ & $\begin{array}{l}\text { Johansen: } \lambda_{\text {trace }} \\
g=0 \text { vs. } g \geq 1\end{array}$ & $\begin{array}{c}\text { Johansen: } \lambda_{\max }=\lambda_{\text {trace }} \\
g=1 \text { vs. } g=2\end{array}$ \\
\hline Bulgaria & -4.17 & $32.73(30.86)$ & $36.53(34.44)$ & $3.81(3.59)$ \\
\hline Czech Republic & -2.21 & $18.78(14.53)$ & $21.75(16.83)$ & $2.97(2.30)$ \\
\hline Hungary & -2.42 & $20.50(18.06)$ & $25.84(22.77)$ & $5.35(4.71)$ \\
\hline Latvia & -2.29 & $41.58(34.83)$ & $48.34(40.50)$ & $6.76(5.66)$ \\
\hline Lithuania & -3.99 & $92.75(74.65)$ & $96.53(77.70)$ & $3.78(3.05)$ \\
\hline Poland & -3.16 & $56.93(48.70)$ & $67.89(58.07)$ & $10.96(9.37)$ \\
\hline Romania & -2.64 & $10.37 \quad(8.22)$ & $16.08(12.76)$ & $5.72(4.54)$ \\
\hline Slovak Republic & -2.03 & $16.46(11.87)$ & $19.26(13.88)$ & $2.79(2.01)$ \\
\hline Slovenia & -7.36 & $46.10(30.41)$ & $54.18(35.74)$ & $8.08(5.33)$ \\
\hline \multicolumn{5}{|c|}{ Panel B: Estimated cointegrating vectors } \\
\hline & $\hat{\beta}$ & $\hat{\gamma}$ & & \\
\hline Bulgaria & -0.017 & -9.543 & & \\
\hline Czech Republic & -0.006 & -17.698 & & \\
\hline Hungary & -0.009 & -4.609 & & \\
\hline Latvia & -0.017 & -12.253 & & \\
\hline Lithuania & -0.018 & -11.307 & & \\
\hline Poland & -0.011 & -6.307 & & \\
\hline Romania & -0.006 & -18.928 & & \\
\hline Slovak Republic & -0.004 & -13.847 & & \\
\hline Slovenia & -0.002 & -20.524 & & \\
\hline
\end{tabular}

Note: The regression tested for cointegration is Equation (4.1) in the text. In Panel A, the ADF test is the relevant augmented Dickey-Fuller test statistic on the residuals from the static equation (4.1), estimated by ordinary least squares. The 5-percent critical values, calculated using the response surface results in MacKinnon (1991), are -3.94 for Bulgaria, -3.91 for Czech Republic, Lithuania, and Slovak Republic, -3.87 for Hungary, -3.90 for Latvia and Romania, -3.88 for Poland, and -3.89 for Slovenia (see Fuller, 1976; MacKinnon, 1991). The Johansen procedure is executed assuming an unrestricted constant term and a deterministic trend that is restricted to lie in the cointegration space; $g$ denotes the number of cointegrating vectors. Figures in parentheses are test statistics adjusted for degrees of freedom (Reimers, 1992). The 5-percent asymptotic critical values are 18.96 and 12.25 (25.32 and 12.25$)$ for the $\lambda_{\max }\left(\lambda_{\text {trace }}\right)$ test statistics for $H_{0}: g=0$ and $H_{0}: g=1$, respectively; the 1-percent asymptotic critical values are 23.65 and 16.26 (30.45 and 16.26) for the $\lambda_{\max }\left(\lambda_{\text {trace }}\right)$ test statistics for $H_{0}: g=0$ and $H_{0}: g=1$, respectively (see Osterwald-Lenum, 1992; Johansen, 1995, chap. 15). In Panel B, we report the maximum-likelihood estimates of the parameters in the cointegrating vector after normalizing the coefficient on $q$ to minus unity.

Table 2

Linearity tests on $\hat{z}_{t}$ : Marginal significance levels ( $p$-values)

\begin{tabular}{l|llll}
\hline \multicolumn{1}{c}{} & \multicolumn{1}{c}{$F^{L}$} & \multicolumn{1}{c}{$F^{3}$} & \multicolumn{1}{c}{$F^{2}$} & $F^{1}$ \\
\cline { 2 - 5 } Bulgaria & $0.4167(\hat{d}=1)$ & 0.3649 & 0.2734 & 0.7765 \\
Czech Republic & $0.0001(\hat{d}=1)$ & 0.0343 & 0.0005 & 0.3759 \\
Hungary & $0.0001(\hat{d}=1)$ & 0.0302 & $0.4 \mathrm{E}-04$ & 0.0066 \\
Latvia & $0.5 \mathrm{E}-04(\hat{d}=2)$ & 0.0028 & $0.5 \mathrm{E}-04$ & 0.1172 \\
Lithuania & $0.0243(\hat{d}=1)$ & 0.8646 & 0.0229 & 0.1573 \\
Poland & $0.0017(\hat{d}=1)$ & 0.0468 & 0.0402 & 0.1061 \\
Romania & $0.1 \mathrm{E}-08(\hat{d}=1)$ & $0.1 \mathrm{E}-04$ & $0.1 \mathrm{E}-07$ & 0.0265 \\
Slovak Republic & $0.1 \mathrm{E}-06(\hat{d}=1)$ & 0.0001 & $0.2 \mathrm{E}-05$ & 0.0182 \\
Slovenia & $0.0111(\hat{d}=1)$ & 0.0179 & 0.0093 & 0.0343 \\
\hline
\end{tabular}

Note: The test statistics $F^{x}$ for $x=L, 3,2,1$ are the Lagrange multiplier test statistics for linearity applied to the residuals retrieved from (4.1), on the basis of the auxiliary regression (4.5), constructed as described in the text; for $F^{L}$ we report the $p$-value corresponding to the value of $d=\hat{d}$ (reported in parentheses) that minimizes the $p$-value. $F^{3}, F^{2}$, and $F^{1}$ are then obtained assuming $d=\hat{d}$. The order of the autoregression, $p$, equals unity. The marginal significance levels are calculated using the appropriate $F$-distribution. 
Table 3

STAR estimation results

\begin{tabular}{|c|c|c|c|c|c|c|c|c|c|}
\hline & $\mu_{10}$ & $\mu_{20}$ & $c_{E}$ & $b$ & $b^{\prime}$ & $\lambda_{E}$ & $R^{2}$ & $E T$ & $A R C H$ \\
\hline Czech Republic & $\begin{array}{l}0.045 \\
(0.020)\end{array}$ & - & $\begin{array}{c}-0.092 \\
(0.032)\end{array}$ & $\begin{array}{l}0.387 \\
(0.159)\end{array}$ & $\begin{array}{c}-0.934 \\
(0.068)\end{array}$ & $\begin{array}{l}0.894 \\
(0.112)\end{array}$ & 0.743 & $\{0.741\}$ & $\{0.422\}$ \\
\hline Hungary & - & - & $\begin{array}{c}-0.080 \\
(0.021)\end{array}$ & $\begin{array}{l}0.179 \\
(0.075)\end{array}$ & $\begin{array}{c}-0.943 \\
(0.211)\end{array}$ & $\begin{array}{l}0.966 \\
(0.122)\end{array}$ & 0.860 & $\{0.485\}$ & $\{0.430\}$ \\
\hline Latvia & - & $\begin{array}{c}-0.448 \\
(0.159)\end{array}$ & - & - & $\begin{array}{c}-0.735 \\
(0.188) \\
\{2 E-05\}\end{array}$ & $\begin{array}{l}0.875 \\
(0.229) \\
\{3 E-04\}\end{array}$ & 0.753 & $\{0.660\}$ & $\{0.387\}$ \\
\hline Lithuania & - & - & - & - & $\begin{array}{c}-0.804 \\
(0.096) \\
\{4 E-06\}\end{array}$ & $\begin{array}{l}0.796 \\
(0.214) \\
\{5 E-04\}\end{array}$ & 0.865 & $\{0.592\}$ & $\{0.673\}$ \\
\hline Poland & - & - & - & - & $\begin{array}{c}-0.676 \\
(0.147) \\
\{9 E-06\}\end{array}$ & $\begin{array}{l}0.843 \\
(0.214) \\
\{1 E-04\}\end{array}$ & 0.643 & $\{0.296\}$ & $\{0.340\}$ \\
\hline Romania & - & $\begin{array}{c}-0.205 \\
(0.088)\end{array}$ & $\begin{array}{c}-0.561 \\
(0.224)\end{array}$ & - & $\begin{array}{c}-0.782 \\
(0.174) \\
\{5 E-04\}\end{array}$ & $\begin{array}{l}0.786 \\
(0.245) \\
\{0.003\}\end{array}$ & 0.767 & $\{0.857\}$ & $\{0.672\}$ \\
\hline Slovak Republic & - & $\begin{array}{c}-0.527 \\
(0.175)\end{array}$ & - & - & $\begin{array}{c}-0.531 \\
(0.072) \\
\{6 E-05\}\end{array}$ & $\begin{array}{l}0.886 \\
(0.264) \\
\{9 E-04\}\end{array}$ & 0.816 & $\{0.471\}$ & $\{0.559\}$ \\
\hline Slovenia & - & - & $\begin{array}{l}0.280 \\
(0.064)\end{array}$ & - & $\begin{array}{c}-0.534 \\
(0.117) \\
\{7 E-10\}\end{array}$ & $\begin{array}{l}0.827 \\
(0.160) \\
\{4 E-07\}\end{array}$ & 0.804 & $\{0.548\}$ & $\{0.440\}$ \\
\hline
\end{tabular}

Note: The estimated model is an ESTAR model of the form (4.4) in each case, applied to the residuals from the regression (4.1), with the delay parameter $d$ set according to the linearity tests results reported in Table 3 and the order of the autoregression $p$ set equal to unity. Figures in parentheses below coefficients estimates and figures in braces denote standard errors and marginal significance levels, respectively. The marginal significance levels are reported only for the estimated coefficients calculated under the null hypothesis that the process contains a unit root and were obtained by Monte Carlo methods as discussed in the text. $R^{2}$ denotes the coefficient of determination; $E T$ and $A R C H$ denote the Eitrheim and Teräsvirta (1996) test statistic for serial correlation and Engle's (1982) test for autoregressive conditional heteroskedasticity up to order 12 , respectively.

stationarity of the residuals and therefore of nonlinear cointegration between $q_{t}$ and $\left(r-r^{*}\right)_{t}$. Moreover, the fact that an ESTAR rather than an LSTAR formulation was selected provides additional support for our results in that it is the more intuitively plausible of the two models for modeling real exchange rate movements.

We then estimated ESTAR models for $\hat{z}_{t}$ for each country considered (except for Bulgaria, for which linearity could not be rejected). The ESTAR estimation results, reported in Table 3, display plausible estimates of the parameters of Equation (4.4) with $b$ either statistically insignificant or small and positive but with $b^{\prime}$ negative, quite large in absolute size, and statistically significantly different from zero. In the light of these estimates and our discussion in Section 4, the linear cointegration results reported above are no longer surprising; in other words, it seems plausible that the no-cointegration hypothesis could not be rejected for some of the countries only because of the inappropriate assumption of linear adjustment toward equilibrium. The residuals $\hat{z}_{t}$ are in fact globally stable and hence stationary, but mean reversion occurs in a nonlinear fashion, with the estimated equilibrium error $\hat{z}_{t}$ behaving like a unit root process near equilibrium (which is itself shifting over time because of movements in the real interest rate differential and the trended component) but reverting to equilibrium very rapidly once the deviation becomes relatively large.

The findings of smooth-transition nonlinearity in the residuals from the static cointegrating regression provided a motivation for considering a smooth-transition regression error correction model. The results from executing the sequence of $F$-tests according to the Teräsvirta rule in an equation of the form (4.13) are reported in Table 4. The linearity tests indicate that linearity is rejected most strongly (and with a very low $p$-value) with $d=1$ for all countries but Latvia, for which the strongest rejection occurs at $d=2$. Again, linearity could not be rejected for Bulgaria. Also the results clearly suggest an ESTR model.

Finally, we estimated the two-equation error correction system (4.10)-(4.11), involving an ESTR for $\Delta q_{t}$ with $d$ set according to the linearity tests results and $p=6$, joint with an ESTR for $\Delta\left(r-r^{*}\right)_{t}$, by multivariate nonlinear least squares. Testing down, we found plausible parsimonious empirical models, given in Table 5. All of the coefficients have quite large $t$-ratios and are of economically plausible signs and magnitudes, and 


\section{Table 4}

Linearity tests on $\hat{v}_{t}$ : Marginal significance levels ( $p$-values)

\begin{tabular}{lcccc}
\hline \multicolumn{1}{c}{$F^{L^{\prime}}$} & $F^{3^{\prime}}$ & $F^{2^{\prime}}$ & $F^{1^{\prime}}$ \\
\cline { 2 - 5 } Bulgaria & $0.4226(\hat{d}=1)$ & 0.4150 & 0.2313 & 0.3539 \\
Czech Republic & $0.0101(\hat{d}=1)$ & 0.4170 & 0.0013 & 0.0039 \\
Hungary & $1 \mathrm{E}-09(\hat{d}=1)$ & 0.0013 & $2 \mathrm{E}-09$ & $1 \mathrm{E}-05$ \\
Latvia & $1 \mathrm{E}-07(\hat{d}=2)$ & 0.0027 & $2 \mathrm{E}-06$ & 0.0097 \\
Lithuania & $0.0257(\hat{d}=1)$ & 0.2634 & 0.0003 & 0.0104 \\
Poland & $0.0001(\hat{d}=1)$ & 0.0089 & 0.0057 & 0.0109 \\
Romania & $5 \mathrm{E}-09(\hat{d}=1)$ & 0.0061 & $1 \mathrm{E}-08$ & 0.0012 \\
Slovak Republic & $0.0003(\hat{d}=1)$ & 0.0317 & 0.0001 & 0.0426 \\
Slovenia & $0.0045(\hat{d}=1)$ & 0.0079 & 0.0036 & 0.0128 \\
\hline
\end{tabular}

Note: The test statistics $F^{x^{\prime}}$ for $x=L, 3,2,1$ are the Lagrange multiplier test statistics for linearity applied to $\hat{v}_{t}$, on the basis of the auxiliary regression (4.13), constructed as described in the text; for $F^{L^{\prime}}$ we report the $p$-value corresponding to the value of $d=\hat{d}$ (reported in parentheses) which minimizes the $p$-value. $F^{3^{\prime}}, F^{2^{\prime}}$, and $F^{1^{\prime}}$ are then obtained assuming $d=\hat{d}$. The order of the autoregression, $p$, equals unity. The marginal significance levels are calculated using the appropriate $F$-distribution.

the equations fit well and pass appropriate diagnostic and adequacy tests (Eitrheim and Teräsvirta, 1996). Whereas the ECM for $\Delta q_{t}$ is highly nonlinear, however, the error correction model for $\Delta\left(r-r^{*}\right)_{t}$ is found to be linear and very parsimonious. ${ }^{12}$

In particular, in the STR model for $\Delta q_{t}$, the coefficient associated with the linear ECM is found to be statistically insignificantly different from zero, so that adjustment toward long-run equilibrium in the model occurs purely in a nonlinear fashion. The coefficient associated with the nonlinear error correction term was very close to minus unity in unrestricted estimation for a number of countries, and we therefore restricted it to minus unity in the final estimation results for those countries (see the likelihood ratio [LR] tests). Also, the speed-of-transition parameter in the exponential function is always statistically significant and of plausible magnitude, albeit varying across countries, and generally indicating a rather high speed of adjustment. The strongly nonlinear adjustment is well captured by the scatters in Figure 1, where we plot the transition variable (the lagged cointegrating residuals) against the estimated nonlinear ECM for each country. Nevertheless, the models for $\Delta\left(r-r^{*}\right)_{t}$ suggest that the change in the real interest rate differential does not respond to the error correction term, and the model collapses to a simple stationary autoregressive process.

Overall, therefore, the empirical results reported in this section suggest that a systematic relationship between real exchange rates and real interest rates exists and that its dynamic representation could be well characterized using a nonlinear error correction model. Also, the real exchange rates appear to follow an appreciating trend and contain a unit root presumably driven by real factors while displaying highly nonlinear dynamics, consistent with the relevant literature and with our priors established in Section 2.

\section{Nonlinear Multivariate Beveridge-Nelson Decompositions}

\subsection{Econometric issues}

Beveridge and Nelson (1981) propose a method for decomposing a univariate time series into its permanent and temporary components in which the permanent component is defined as the long-horizon level forecast of the series, or the part that remains after all transitory dynamics have worked themselves out. This was

\footnotetext{
${ }^{12}$ Note that we started with the estimation of the system (4.10)-(4.11), hence allowing also the equation for the $\Delta\left(r-r^{*}\right)_{t}$ to be nonlinear. In each case, however, the general-to-specific procedure led us to a linear specification for $\Delta\left(r-r^{*}\right)_{t}$. Also, note that the constant terms are restricted in the system estimation for consistency with the cointegration results reported in Table 1.
} 

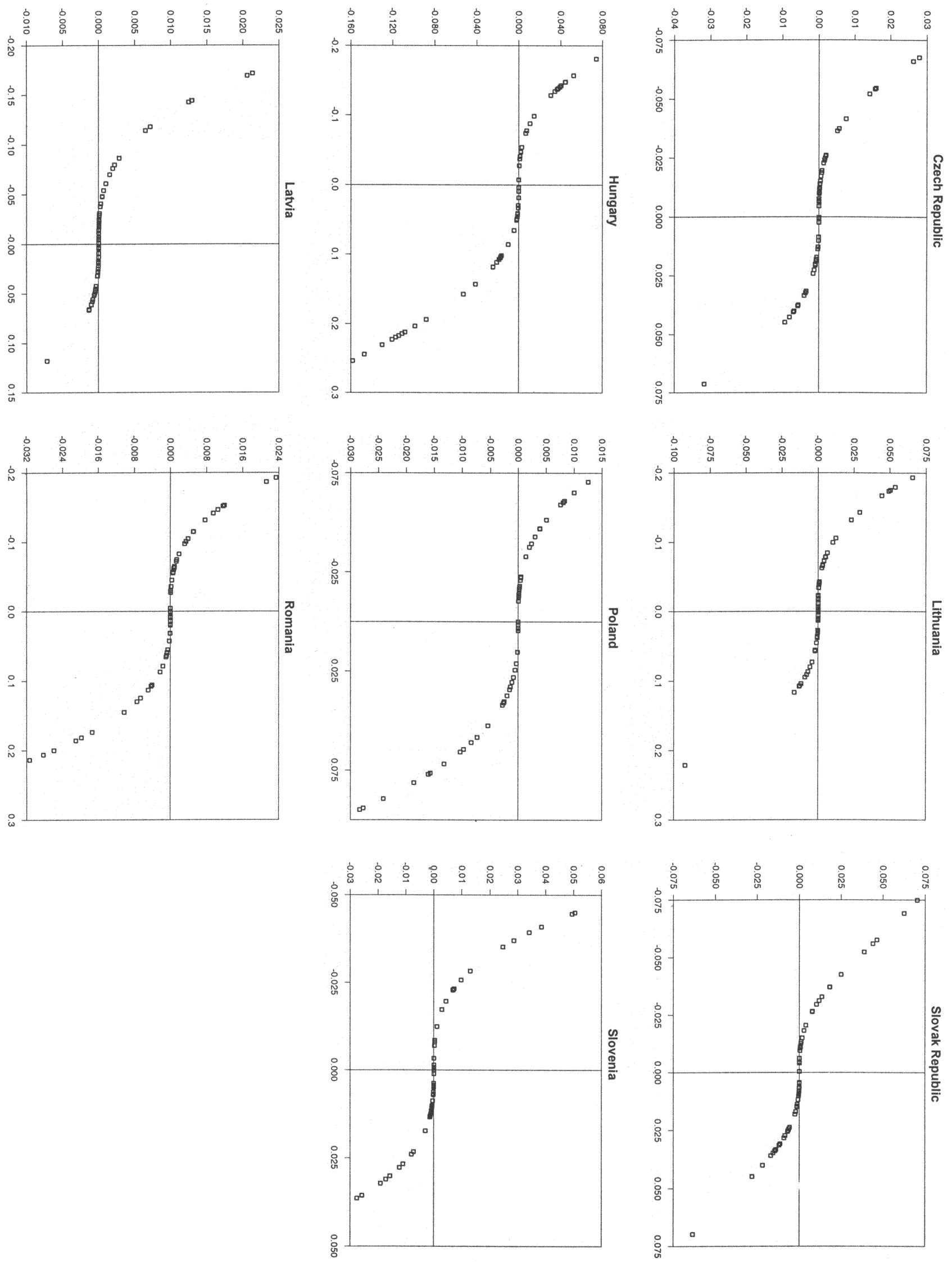

Figure 1

Estimated nonlinear error corrections. 
Table 5

Estimated equilibrium correction systems

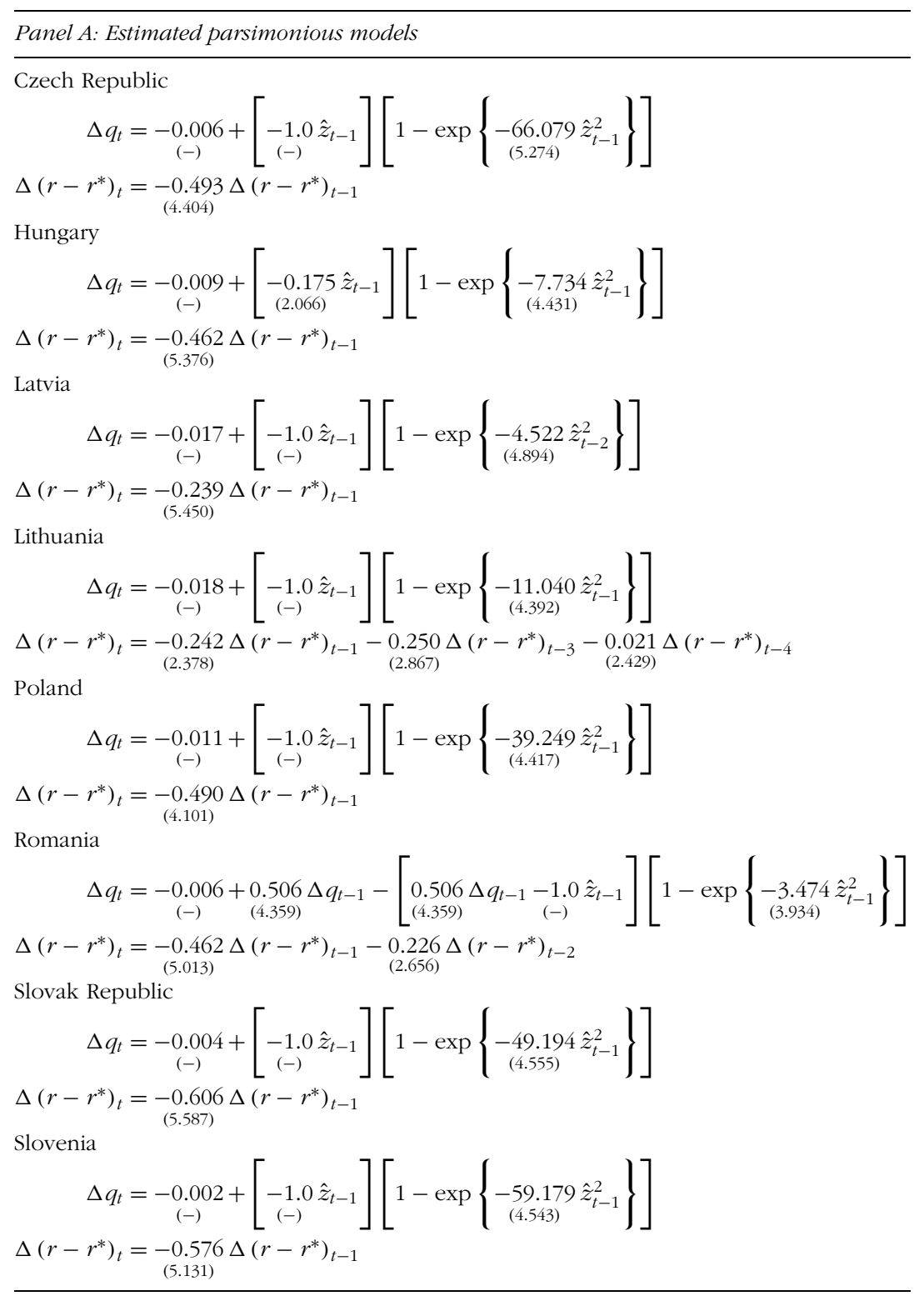

generalized to the multivariate case by Stock and Watson (1987) and applied, for example, by Cochrane (1994). For a multivariate, $N \times 1$ vector $\boldsymbol{Z}_{t}$, the trend or permanent component, $\boldsymbol{Z}_{t}^{\pi}$, may be defined as:

$$
\boldsymbol{Z}_{t}^{\pi}=\lim _{h \rightarrow \infty}\left\{E\left(\boldsymbol{Z}_{t+h} \mid I_{t}\right)-h\left[E\left(\boldsymbol{Z}_{t+h} \mid I_{t}\right)-E\left(\boldsymbol{Z}_{t+h-1} \mid I_{t}\right)\right]\right\}
$$

where $I_{t}=\left\{\boldsymbol{Z}_{t}, \boldsymbol{Z}_{t-1}, \boldsymbol{Z}_{t-2}, \ldots\right\}$ is the information set consisting of current and lagged values of the time-series vector. The transitory or cycle component, $\boldsymbol{Z}_{t}^{\tau}$, is defined as the complement to the permanent component:

$$
\boldsymbol{Z}_{t}^{\tau}=\boldsymbol{Z}_{t}-\boldsymbol{Z}_{t}^{\pi}
$$

The permanent component is simply the level that is expected to prevail in the long run, minus that part of the long-run level that is due to a purely deterministic trend component between now and then. If the vector time series is not explosive, then for large enough $h, \boldsymbol{Z}_{t+b}$ will enter steady state such that it increases in each 
Table 5

Continued.

\begin{tabular}{lcccccc}
\hline Panel B: Diagnostic statistics & & & & & \\
equation for & & $R^{2}$ & $S C$ & $A R C H$ & $J B$ & $L R$ \\
\cline { 2 - 6 } Czech Republic & $\Delta q_{t}$ & 0.951 & $\{0.236\}$ & $\{0.456\}$ & $\{0.648\}$ & $\{0.402\}$ \\
& $\Delta\left(r-r^{*}\right)_{t}$ & 0.559 & $\{0.448\}$ & $\{0.479\}$ & $\{0.601\}$ & $\{0.749\}$ \\
Hungary & $\Delta q_{t}$ & 0.822 & $\{0.473\}$ & $\{0.745\}$ & $\{0.742\}$ & $\{0.431\}$ \\
& $\Delta\left(r-r^{*}\right)_{t}$ & 0.633 & $\{0.530\}$ & $\{0.381\}$ & $\{0.713\}$ & $\{0.480\}$ \\
Latvia & $\Delta q_{t}$ & 0.986 & $\{0.402\}$ & $\{0.457\}$ & $\{0.545\}$ & $\{0.384\}$ \\
& $\Delta\left(r-r^{*}\right)_{t}$ & 0.312 & $\{0.559\}$ & $\{0.530\}$ & $\{0.460\}$ & $\{0.551\}$ \\
Lithuania & $\Delta q_{t}$ & 0.971 & $\{0.341\}$ & $\{0.283\}$ & $\{0.382\}$ & $\{0.299\}$ \\
Poland & $\Delta\left(r-r^{*}\right)_{t}$ & 0.277 & $\{0.466\}$ & $\{0.237\}$ & $\{0.745\}$ & $\{0.636\}$ \\
& $\Delta q_{t}$ & 0.968 & $\{0.536\}$ & $\{0.385\}$ & $\{0.441\}$ & $\{0.237\}$ \\
Romania & $\Delta\left(r-r^{*}\right)_{t}$ & 0.549 & $\{0.874\}$ & $\{0.239\}$ & $\{0.536\}$ & $\{0.395\}$ \\
& $\Delta q_{t}$ & 0.772 & $\{0.285\}$ & $\{0.348\}$ & $\{0.329\}$ & $\{0.526\}$ \\
Slovak Republic & $\Delta\left(r-r^{*}\right)_{t}$ & 0.218 & $\{0.653\}$ & $\{0.439\}$ & $\{0.340\}$ & $\{0.442\}$ \\
& $\Delta q_{t}$ & 0.909 & $\{0.640\}$ & $\{0.326\}$ & $\{0.437\}$ & $\{0.431\}$ \\
Slovenia & $\Delta\left(r-r^{*}\right)_{t}$ & 0.258 & $\{0.733\}$ & $\{0.551\}$ & $\{0.273\}$ & $\{0.568\}$ \\
& $\Delta q_{t}$ & 0.938 & $\{0.347\}$ & $\{0.477\}$ & $\{0.286\}$ & $\{0.450\}$ \\
& $\Delta\left(r-r^{*}\right)_{t}$ & 0.283 & $\{0.642\}$ & $\{0.845\}$ & $\{0.642\}$ & $\{0.746\}$ \\
\hline
\end{tabular}

Note: The models for $\Delta q_{t}$ and $\Delta\left(r-r^{*}\right)_{t}$ are obtained by employing a general-to-specific procedure starting from the system (4.10)-(4.11) with $p=6$ and $d=1$ for all countries except for Latvia, where $d=2$. Estimation is by multivariate nonlinear least squares. Figures in parentheses below coefficient estimates denote $t$-ratios. Figures in braces denote marginal significance levels ( $p$-values). $R^{2}$ is the coefficient of determination; SC and ARCH denote a test statistic for serial correlation and Engle's (1982) test for autoregressive conditional heteroskedasticity up to order 12, respectively (SC is the Eitrheim and Teräsvirta, 1996, test statistic for serial correlation when referred to the nonlinear ECM for $\Delta q_{t}$, and it is the Ljung-Box test statistic when referred to the linear autoregressive model for $\left.\Delta\left(r-r^{*}\right)_{t}\right)$; JB is the Jarque-Bera test for normality of the residuals; $L R$ is a likelihood ratio test for the restrictions imposed in the relevant parsimonious model relative to an unrestricted STR model as in the system (4.10)-(4.11) with $p=6$.

period only by a constant trend of, say, $\mu$ per period:

$$
\mu=\lim _{h \rightarrow \infty}\left\{E\left(\boldsymbol{Z}_{t+h} \mid I_{t}\right)-E\left(\boldsymbol{Z}_{t+b-1} \mid I_{t}\right)\right\}
$$

Hence, the last bracketed term in (6.1) extracts the deterministic trend component that has accumulated in the long-horizon prediction. Further insight into the Beveridge-Nelson decomposition may be obtained by substituting (6.3) into (6.1) and rearranging:

$$
\boldsymbol{Z}_{t}^{\pi}=\boldsymbol{Z}_{t}+\lim _{b \rightarrow \infty} \sum_{j=1}^{b}\left\{E\left[(1-L) \boldsymbol{Z}_{t+j} \mid I_{t}\right]-\mu\right\}
$$

where $L$ is the lag operator. Thus, the Beveridge-Nelson permanent or trend component of $\boldsymbol{Z}_{t}$ is just $\boldsymbol{Z}_{t}$ itself plus all expected future growth in $\boldsymbol{Z}_{t}$ above the deterministic growth rate. If an element of $\boldsymbol{Z}_{t}$ is expected to grow above its average growth rate in the future (i.e., the corresponding element of $\mu$ ), then that element of $\boldsymbol{Z}_{t}$ will be below its permanent or trend level.

Clarida and Taylor (2001) consider an extension of the Beveridge-Nelson decomposition to the case in which the data-generating process for $\boldsymbol{Z}_{t}$ is nonlinear. The extension they suggest follows from calculating the permanent and temporary components of $\boldsymbol{Z}_{t}$ exactly as defined above but where the long-horizon conditional predictions are generated by explicitly taking account of the nonlinear data-generating process for $\boldsymbol{Z}_{t}$. The justification for treating the component of $\boldsymbol{Z}_{t}$ defined in (6.1), in the nonlinear case, as the permanent component of $\boldsymbol{Z}_{t}$ is exactly as in the linear case: the long-horizon prediction less any component that has 
accumulated because of a purely deterministic trend component must be equal to the level that the series will reach after all transitory dynamics have worked themselves out. ${ }^{13}$

A major difficulty in implementing the Beveridge-Nelson decomposition in a nonlinear framework arises, however, from the difficulty of forming multistep forecasts. In general, exact conditional multistep prediction involves multiple integration over the probability space of the innovation process (see Granger and Teräsvirta, 1993, chap. 8). Following Clarida and Taylor (2001), this difficulty may be circumvented using Monte Carlo integration, which involves using the estimated model to simulate a large number of forecast paths and then taking the average path as the conditional forecast. For a large number of replications, this will be arbitrarily close to the exact conditional forecast (see, e.g., see Gallant, Rossi, and Tauchen, 1993; Granger and Teräsvirta, 1993).

\subsection{Empirical results}

We next carried out the nonlinear multivariate Beveridge-Nelson decomposition using Monte Carlo integration to provide multistep forecasts from the estimated models given in Table 5 and assuming a bivariate Gaussian distribution for the error terms with a covariance matrix calibrated, for each country, on the estimated covariance matrix. We used 5,000 Monte Carlo replications for each data point and forecasted 100 steps ahead (with a check that the forecasts had in fact entered steady state).

The resulting permanent and temporary components of the real exchange rate series examined are graphed in Figure 2. We graphed in each column the actual real exchange rate series, the permanent (deterministic plus stochastic) trend component, and the temporary component for the country in question. The graphs suggest very clearly that the permanent trend component largely dominates the temporary component for each country, although the temporary component is of varying importance across countries. This finding is in line with the view that purchasing power parity (i.e., a stable equilibrium level for the real exchange rate) is inadequate in the context of real exchange rates of transition economies, which appear to be largely characterized by a strongly appreciating trend. The results also confirm our view that real shocks are likely to be far more important than nominal (e.g., monetary or financial) shocks in driving real exchange rate movements in these countries over the sample examined.

\section{Conclusions}

In this paper we have examined the behavior of the real exchange rate of nine transition economies (Bulgaria, the Czech Republic, Hungary, Latvia, Lithuania, Poland, Romania, the Slovak Republic, and Slovenia) during the 1990s. Consistent with standard exchange rate determination models in the tradition of MFD and HBS, we estimated a model that allows explicitly for real interest rate differentials and (implicitly) for productivity differentials to have an impact on real exchange rates and therefore generate permanent deviations from PPP. In addition, we employed nonlinear modeling techniques to capture the behavior of the equilibrium error of the long-run model proposed, consistent with some recent theoretical literature on real exchange rate determination as well as with some observed regularities in real exchange rate behavior.

Our empirical results are encouraging in that we were able to detect a long-run systematic relationship between real exchange rates and real interest rate differentials while capturing the observed appreciating trend of the transition economies' real exchange rates and obtaining plausible estimated nonlinear models. The nonlinear error correction models selected were then used to decompose the real exchange rate series of these transition economies into their permanent and temporary components using a nonlinear generalization

\footnotetext{
${ }^{13}$ In the linear case, the fact that Beveridge and Nelson consider only $I(1)$ processes means that the condition (6.3) is automatically satisfied. In considering the nonlinear case, some analogous restrictions on the limiting behavior of the differenced series are imposed. See Clarida and Taylor (2001) for details.
} 

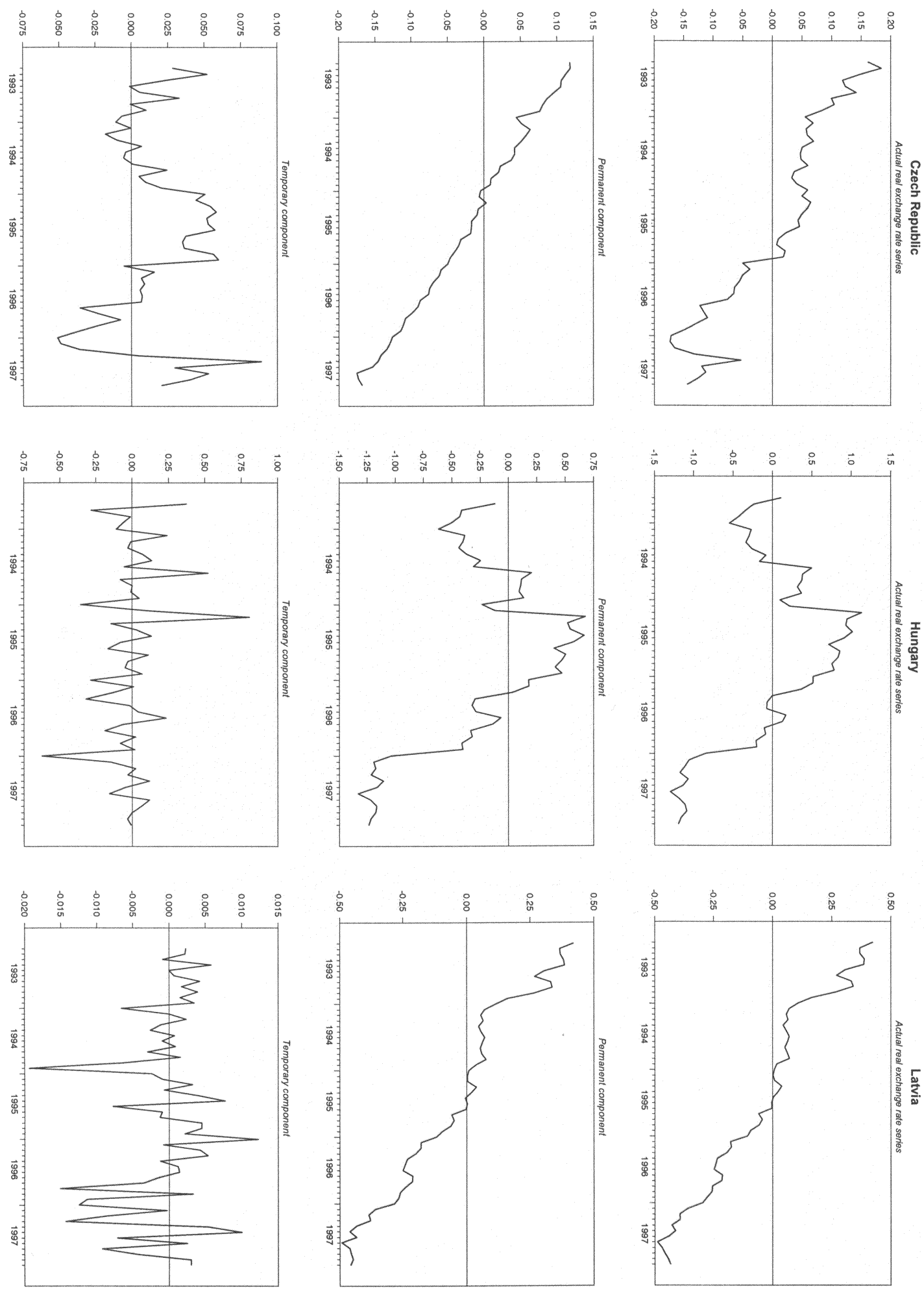

Figure 2

Nonlinear multivariate Beveridge-Nelson decompositions. Panel A: Czech Republic, Hungary, and Latvia 

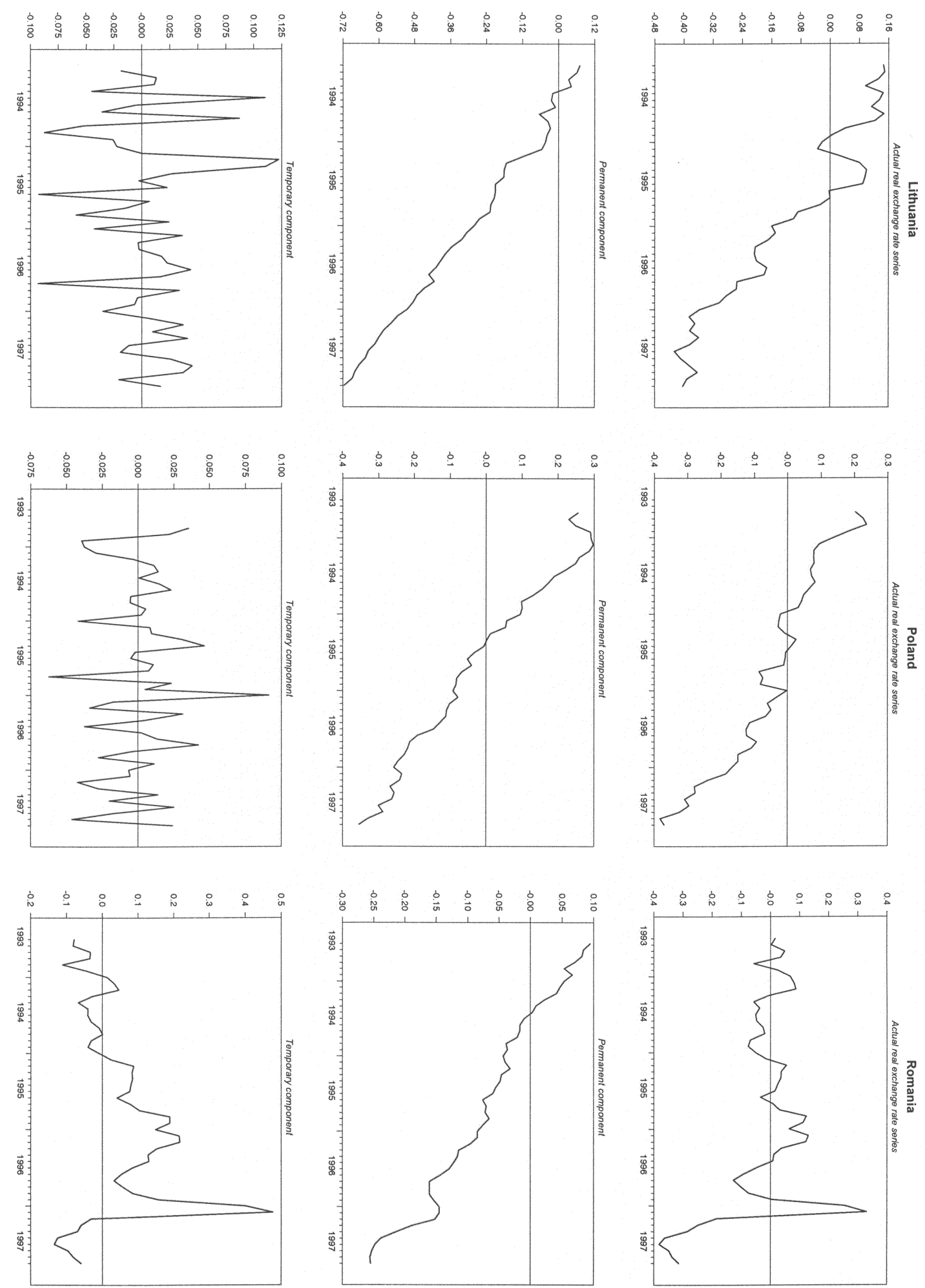

Panel B: Lithuania, Poland, and Romania 

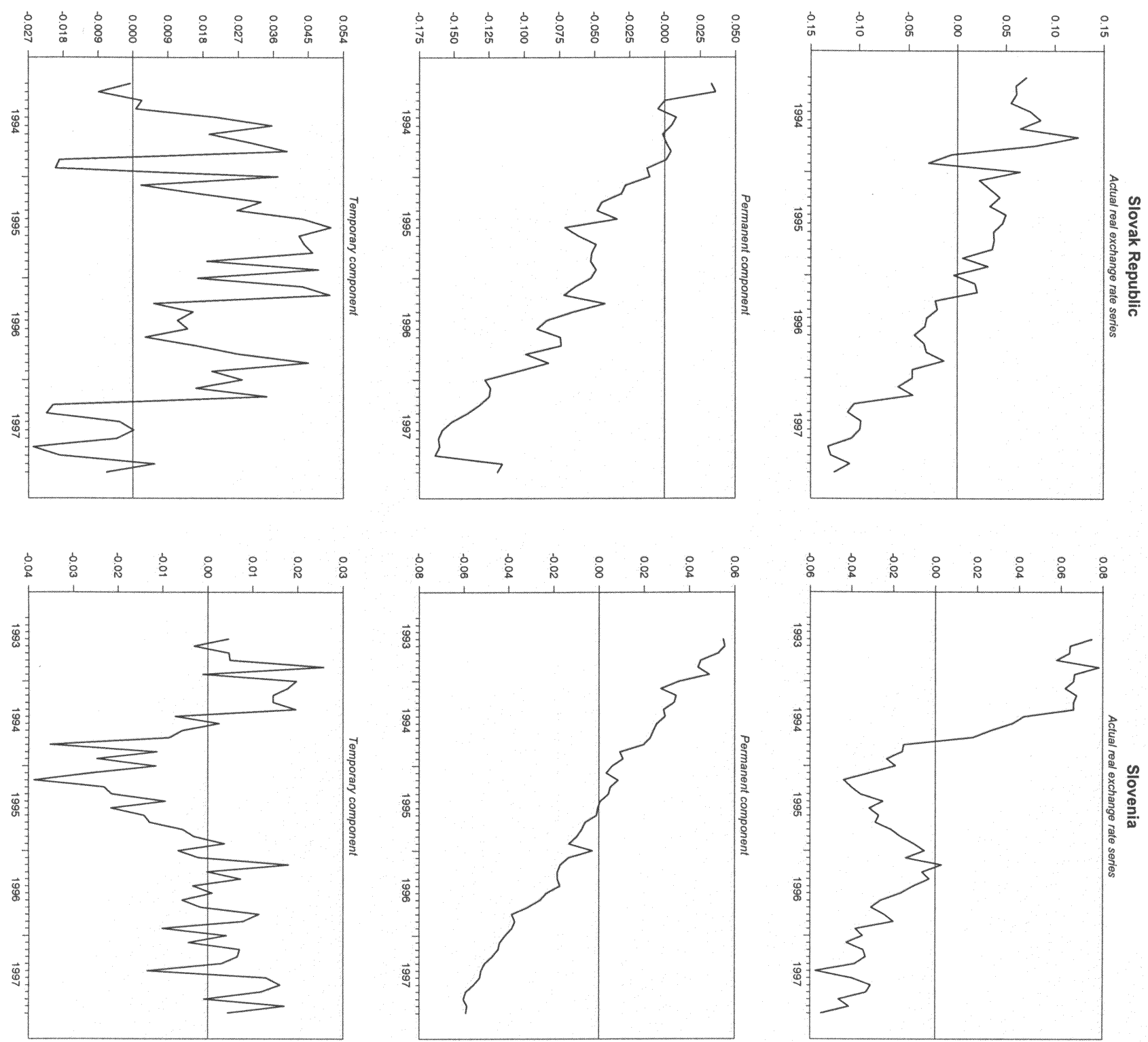

Panel C: Slovak Republic and Slovenia

of the multivariate Beveridge-Nelson decomposition. The results from executing the decomposition suggested that, in fact, the permanent component largely dominates the real exchange rate series of each of the economies examined. This permanent component may be driven by HBS effects, although it may be the case that HBS effects represent only part of the full story. For example, the continuous real appreciation may be needed to attract labor away from the state sector, which is then forced to close down inefficient production lines. Although identification of the relative importance of HBS effects and these labor effects obviously represents an avenue for future research, our results suggest that the real exchange rates of these economies display behavior not inconsistent with standard economic theory concerning exchange rate movements. Nevertheless, the empirical results also have important policy implications. In particular, it may be difficult and perhaps harmful to resist the observed real appreciation at this stage of the transition, since the real appreciation is a logical consequence of liberalization and it is the market channel through which labor may be attracted out of the inefficient state sector toward the emerging private sector. 
The transition process is still ongoing, with the transition countries possibly facing different stages of the process. By definition, however, a transition economy is on a path to somewhere. It seems clear that the real exchange rate appreciation experienced by the currencies examined in this paper cannot be sustained indefinitely. As transition economies catch up relative to industrialized countries, the real exchange rate appreciation may be expected to slow down and eventually end. ${ }^{14}$

\section{References}

Abuaf, N., and P. Jorion (1990). "Purchasing power parity in the long run." Journal of Finance, 45: 157-174.

Adler, M., and B. Lehmann (1983). "Deviations from purchasing power parity in the long run." Journal of Finance, 38: $1471-1487$.

Bahmani-Oskooee, M., and H. J. Rhee (1996). "Time-series support for Balassa's productivity-bias hypothesis: Evidence from Korea." Review of International Economics, 4: 364-370.

Balassa, B. (1964). "The purchasing power parity doctrine: A reappraisal." Journal of Political Economy, 72: $584-596$.

Balke, N. S., and T. B. Fomby (1997). "Threshold cointegration.” International Economic Review, 38: 627-645.

Baxter, M. (1994). "Real exchange rates and real interest differentials: Have we missed the business-cycle relationship?" Journal of Monetary Economics, 33: 5-37.

Benninga, S., and A. A. Protopapadakis (1988). "The equilibrium pricing of exchange rates and assets when trade takes time." Journal of International Economics, 7: 129-149.

Beveridge, S., and C. R. Nelson (1981). "A new approach to decomposition of economic time series into permanent and transitory components with particular attention to measurement of the "business cycle." Journal of Monetary Economics, 7: 151-174

Breuer, J. B. (1994). "An assessment of the evidence on purchasing power parity." In John Williamson (ed.), Estimating Equilibrium Exchange Rates. Washington, DC: Institute for International Economics, pp. 245-277.

Breuer, J. B., and A. F. Lippert (1997). "Internal relative price stationarity in long-run purchasing power parity." Review of International Economics, 5: 195-203.

Campbell, J. Y., and R. H. Clarida (1987). "The dollar and real interest rates: An empirical investigation." Carnegie Rochester Conference Series on Public Policy, 27: 103-140.

Cheung, Y. W., and K. S. Lai (1993a). "Long-run purchasing power parity during the recent float." Journal of International Economics, 34: 181-192.

Cheung, Y. W., and K. S. Lai (1993b). "A fractional cointegration analysis of purchasing power parity." Journal of Business Economics and Statistics, 11: 103-112.

Cheung, Y. W., and K. S. Lai (1993c). "Finite-sample sizes of Johansen's likelihood ratio tests for cointegration." Oxford Bulletin of Economics and Statistics, 55: 313-328.

Cheung, Y. W., and K. S. Lai (1998). "Parity reversion in real exchange rates during the post-Bretton Woods period." Journal of International Money and Finance, 17: 597-614.

Chinn, M., and L. Johnston (1997). "Real exchange rate levels, productivity and demand shocks: Evidence from a panel of 14 countries." Working paper no. WP/97/66. Washington, DC: International Monetary Fund.

\footnotetext{
${ }^{14}$ It is perhaps worth distinguishing between the various meanings of "permanent" as applied in this context. Strong productivity growth in transition economies will tend to effect an appreciation of the real exchange rate vis-à-vis a developed economy that is permanent in the sense that it will have no tendency to correct itself. On the other hand, we do not expect this behavior to be a permanent feature of the real exchange rate once the transition process is complete.

An anonymous reviewer made an interesting analogy between the behavior of the real exchange rates of transition economies during the sample examined here and the behavior of the real mark/dollar rate (with the mark being the appreciating currency) during the transition following the end of the post-Bretton Woods period in 1973 until around 1978 (see Frankel, 1979, 1981). Of course, we know that over a span covering the recent float since 1973, we do not observe appreciation of the real mark/dollar rate, and we cannot provide convincing evidence in favor of a systematic relationship between the real mark/dollar rate and the corresponding real interest rate differential, so that clearly the appreciating behavior of the mark/dollar rate was a short-span phenomenon. Our results in this paper may be interpreted in a similar fashion.
} 
Clarida, R. H., and M. P. Taylor (2001). "Nonlinear permanent-temporary decompositions, with applications in macroeconomics and finance." Mimeographed. New York: Columbia University and Coventry, UK: University of Warwick.

Cochrane, J. H. (1994). "Permanent and transitory components of GNP and stock prices." Quarterly Journal of Economics, 109: 241-265.

De Broeck, M., and T. Slok (2001). "Interpreting real exchange rate movements in transition economies." Working paper no. WP/01/56. Washington, DC: International Monetary Fund.

Dornbusch, R. (1976). "Expectations and exchange rate dynamics.” Journal of Political Economy, 84: 1161-1176.

Dornbusch, R. (1987). "Purchasing power parity." In J. Eatwell, M. Milgate, and P. Newman (eds.), The New Palgrave: A Dictionary of Economics. London: Macmillan and New York: Stockton Press, pp. 1075-1085.

Dumas, B. (1992). "Dynamic equilibrium and the real exchange rate in spatially separated world." Review of Financial Studies, 5: 153-180.

Edison, H. J. (1987). "Purchasing power parity in the long run." Journal of Money, Credit and Banking, 19: 376-387.

Edison, H. J., J. E. Gagnon, and W. R. Melick (1997). "Understanding the empirical literature on purchasing power parity: The post-Bretton Woods era." Journal of International Money and Finance, 16: 1-17.

Edison, H. J., and W. R. Melick (1999). "Alternative approaches to real exchange rates and real interest rates: Three up and three down." International Journal of Finance and Economics, 4: 93-111.

Edison, H. J., and B. D. Pauls (1993). "A re-assessment of the relationship between real exchange rates and real interest rates: 1974-1990.” Journal of Monetary Economics, 31: 165-187.

Eitrheim, O., and T. Teräsvirta (1996). "Testing the adequacy of smooth transition autoregressive models." Journal of Econometrics, 74: 59-75.

Enders, W. (1988). "ARIMA and cointegration tests of PPP under fixed and flexible exchange rate regimes." Review of Economics and Statistics, 70: 504-508.

Enders, W., and B. Falk (1998). "Threshold-autoregressive, median-unbiased, and cointegration tests of purchasing power parity." International Journal of Forecasting, 14: 171-186.

Engle, R. F. (1982). "Autoregressive conditional heteroskedasticity with estimates of the variance of the United Kingdom inflation.” Econometrica, 55: 987-1007.

Engle, R. F., and C. W. J. Granger (1987). "Cointegration and error correction: Representation, estimation and testing." Econometrica, 55: 251-276.

Fisher, E. O., and J. Y. Park (1991). "Testing purchasing power parity under the null hypothesis of co-integration." Economic Journal, 101: 1476-1484.

Fleming, J. M. (1962). "Domestic financial policies under fixed and under floating exchange rates." IMF Staff Papers, 9: 369-379.

Frankel, J. A. (1979). "On the mark: A theory of floating exchange rates based on real interest differentials." American Economic Review, 69: 610-622.

Frankel, J. A. (1981). "On the Mark: Reply." American Economic Review, 71: 1075-1082.

Frankel, J. A., and A. K. Rose (1996). "A panel project on purchasing power parity: Mean reversion within and between countries." Journal of International Economics, 40: 209-224.

Froot, K. A., and K. Rogoff (1995). "Perspectives on PPP and long-run real exchange rates." In K. Rogoff and G. Grossman (eds.), Handbook of International Economics. Amsterdam: North Holland.

Fuller, W. A. (1976). Introduction to Statistical Time Series. New York: Wiley and Sons, pp. 1647-1688.

Gallant, A. R., P. E. Rossi, and G. Tauchen (1993). "Nonlinear dynamic structures.” Econometrica, 61: 871-908.

Grafe, C., and C. Wyplosz (1999). "A model of the real exchange rate determination in transition economies." In M. Blejer and M. Škreb (eds.), Balance of Payments, Exchange Rates, and Competitiveness in Transition Economies. Boston: Kluwer Academic, pp. 159-184.

Granger, C. W. J., and N. Swanson (1996). "Further developments in the study of cointegrated variables." Oxford Bulletin of Economics and Statistics, 58: 537-553. 
Granger, C. W. J., and T. Teräsvirta (1993). Modelling Nonlinear Economic Relationships. Oxford: Oxford University Press.

Halpern, L., and C. Wyplosz (1997). "Equilibrium exchange rates in transition economies.” IMF Staff Papers, 44: $430-461$.

Harrod, R. (1933). International Economics. London: James Nisbet and Cambridge University Press.

Hegwood, N. D., and D. H. Papell (1998). "Quasi purchasing power parity." International Journal of Finance and Economics, 3: 279-289.

Johansen, S. (1988). "Statistical analysis of cointegrating vectors." Journal of Economic Dynamics and Control, 12: 231-254.

Johansen, S. (1991). "Estimation and hypothesis testing of cointegrating vectors in Gaussian vector autoregressive models." Econometrica, 59: 1551-1580.

Johansen, S. (1995). Likelihood-Based Inference in Cointegrated VAR Models. Oxford: Oxford University Press.

Johansen, S. (2000). "A small sample correction of the test for cointegrating rank in the vector autoregressive model." Working Paper ECO no. 2000/15. Florence, Italy: European University Institute.

Kim, Y. (1990). "Purchasing power parity in the long run: A cointegration approach." Journal of Money, Credit and Banking, 22: $348-357$.

Kouretas, G. P. (1997). "The Canadian dollar and purchasing power parity during the recent float." Review of International Economics, 5: 467-477.

Krajnyak, K., and J. Zettelmeyer (1998). "Competitiveness in transition economies: What scope for real appreciation?" IMF Staff Papers, 45: 309-362.

Lothian, J. R., and M. P. Taylor (1996). "Real exchange rate behavior: The recent float from the perspective of the past two centuries." Journal of Political Economy, 104: 488-510.

Lothian, J. R., and M. P. Taylor (1997). "Real exchange rate behavior: The problem of power and sample size." Journal of International Money and Finance, 16: 945-954.

Luukkonen, R., P. Saikkonen, and T. Teräsvirta (1988). "Testing linearity against smooth transition autoregressive models." Biometrika, 75: 491-499.

MacKinnon, J. G. (1991). "Critical values for cointegration tests.” In R. F. Engle and C. W. J. Granger (eds.), Long-Run Economic Relationships: Readings in Cointegration. Oxford: Oxford University Press, pp. 267-276.

Mark, N. (1990). "Real and nominal exchange rates in the long run: An empirical investigation." Journal of International Economics, 28: 115-136.

Meese, R. A., and K. Rogoff (1988). "Was it real? The exchange rate-interest differential relation over the modern floating-rate period." Journal of Finance, 43: 933-948.

Michael, P., A. R. Nobay, and D. A. Peel (1997). "Transaction costs and nonlinear adjustment in real exchange rates: An empirical investigation." Journal of Political Economy, 105: 862-879.

Mundell, R. A. (1961). "A theory of optimum currency areas.” American Economic Review, 51: 657-665.

Obstfeld, M., and K. Rogoff (1996). Foundations of International Macroeconomics. Cambridge: MIT Press.

Obstfeld, M., and A. M. Taylor (1998). "Nonlinear aspects of goods-market arbitrage and adjustment: Heckscher's commodity points revisited." Journal of the Japanese and International Economies, 11: 441-479.

Officer, L. H. (1982). Purchasing Power Parity and Exchange Rates: Theory, Evidence and Relevance. Greenwich, CT: JAI Press.

Osterwald-Lenum, M. (1992). "A note with quantiles of the asymptotic distribution of the maximum likelihood cointegration rank test statistics." Oxford Bulletin of Economics and Statistics, 54: 461-472.

Papell, D. H. (1998). "Searching for stationarity: Purchasing power parity under the current float." Journal of International Economics, 43: 313-332.

Papell, D. H. (1999). "The great appreciation, the great depreciation, and the purchasing power parity hypothesis." Paper presented at the 1999 American Economic Association annual meetings, New York. Mimeographed. Houston: Department of Economics, University of Houston.

Peel, D. A., and A. E. H. Speight (1996). "Non-linearities in east European black-market exchange rates." International Journal of Finance and Economics, 2: 39-57. 
Reimers, H.-E. (1992). "Comparison of tests for multivariate cointegration.” Statistical Papers, 33: 335-359.

Rogoff, R. (1996). "The purchasing power parity puzzle." Journal of Economic Literature, 34: 647-668.

Samuelson, P. A. (1964). "Theoretical notes on trade problems." Review of Economics and Statistics, 46: 145-154.

Sarno, L. (2000). "Real exchange rate behaviour in the Middle East: A re-examination." Economics Letters, 66: 127-136.

Sarno, L., and M. P. Taylor (1998). "Real exchange rates under the recent float: Unequivocal evidence of mean reversion." Economics Letters, 60: 131-137.

Sarno, L., and M. P. Taylor (2001). "Purchasing power parity and the real exchange rate." Centre for Economic Policy Research discussion paper no. 2913, August, forthcoming International Monetary Fund Staff Papers.

Sercu, P., R. Uppal, and C. Van Hulle (1995). "The exchange rate in the presence of transactions costs: Implications for tests of purchasing power parity." Journal of Finance, 50: 1309-1319.

Stock, J. H. (1997). "Cointegration, long-run movements, and long-horizon forecasting.” In D. M. Kreps and K. F. Wallis (eds.), Advances in Economics and Econometrics: Theory and Applications, Seventh World Congress, vol. 3. Cambridge: Cambridge University Press, pp. 34-60.

Stock, J. H., and M. W. Watson. (1987). "Testing for common trends." Journal of the American Statistical Association, 83: 1097-1107.

Taylor, M. P. (1988). "An empirical examination of long-run purchasing power parity using cointegration techniques." Applied Economics, 20: 1369-1381.

Taylor, M. P. (1995). "The economics of exchange rates.” Journal of Economic Literature, 33: 13-47.

Taylor, M. P., D. A. Peel, and L. Sarno (2001). "Nonlinear mean-reversion on real exchange rates: Toward a solution to the purchasing power parity puzzles.” International Economic Review, 42: 1015-1042.

Taylor, M. P., and L. Sarno (1998). "The behavior of real exchange rates during the post Bretton Woods period." Journal of International Economics, 46: 281-312.

Teräsvirta, T. (1994). "Specification, estimation and evaluation of smooth transition autoregressive models." Journal of the Americal Statistical Association, 89: 208-218.

Teräsvirta, T. (1998). "Modelling economic relationships with smooth transition regressions." In D. E. A. Giles and A. Ullah (eds.), Handbook of Applied Economic Statistics. New York: Marcel Dekker, pp. 507-552.

Tong, H. (1990). Non-Linear Time Series: A Dynamic System Approach. Oxford: Clarendon.

Wu, Y. (1996). "Are real exchange rates non-stationary? Evidence from a panel-data test." Journal of Money, Credit and Banking, 28: 54-63. 